Research Article

\title{
Investigation of Influencing Factors on the Deformation of Sheet Pile Wall with a Relieving Platform
}

\author{
Ming Zhang $\mathbb{D}^{1}{ }^{1}$ Wei Wang $\mathbb{D},{ }^{2}$ Ronghua $\mathrm{Hu}^{3}$ and Ziyi Wang ${ }^{4}$ \\ ${ }^{1}$ Institute of Civil Engineering, Henan University of Engineering, Xianghe Rd 1, Zhengzhou 451191, China \\ ${ }^{2}$ College of Architecture and Urban Planning, Beijing University of Technology, Pingleyuan Rd 100, Beijing 100124, China \\ ${ }^{3}$ Amer International Group Co. Ltd., West Hongli Rd 8133, Shenzhen 518040, China \\ ${ }^{4}$ College of Architecture and Civil Engineering, Beijing University of Technology, Pingleyuan Rd 100, Beijing 100124, China \\ Correspondence should be addressed to Wei Wang; ieeww@bjut.edu.cn
}

Received 10 October 2020; Revised 24 January 2021; Accepted 31 January 2021; Published 11 February 2021

Academic Editor: Jinyang Xu

Copyright ( $\odot 2021$ Ming Zhang et al. This is an open access article distributed under the Creative Commons Attribution License, which permits unrestricted use, distribution, and reproduction in any medium, provided the original work is properly cited.

\begin{abstract}
Owing to the complexity of the sheet pile wall with a relieving platform, there are a large number of factors that affect the mechanical and deformation characteristics of the wall structure. Moreover, studying the influencing factors on the deformation of the retaining wall is beneficial in the selection of design parameters and deformation control. 28 groups of test models of the retaining wall structure are designed to analyze the effect on the deformation of rib pillars and determine the reasonable width and buried depth of the unloading board in this paper. The tests are conducted with and without the unloading board, and different widths and buried depths of the unloading board are also considered. The findings show that, without the external load, the reasonable board width and buried depth are 0.70 times and 0.53 times the wall height. With the external load, the reasonable board width is 0.35 times the wall height, and the large board width cannot effectively reduce the deformation of rib pillars, and the reasonable board width is 0.60 times the wall height. When both the external load and board width are relatively small, the reasonable buried depth is 0.53 times the wall height. However, when the external load is large, the reasonable buried depth is 0.70 times the wall height. The results also show that the setting of the unloading board effectively suppresses the deformation of rib pillars and controls the maximum deformation within an allowable range of the specification.
\end{abstract}

\section{Introduction}

A sheet pile wall with a relieving platform mainly consists of piles, top beams, counterfort, wall surface plate, and unloading board. The retaining wall has some advantages of sheet pile wall and retaining wall with relieving platforms, and it has the characteristics of safety, economy, aesthetics, easy construction, and reasonable force. It has been successfully applied in the 10- to 15-meter-height slope (landslide) retaining engineering. Because of the complexity of the retaining wall structure, the mechanics and deformation characteristics are very complicated. Many scholars have studied the mechanical behaviors [1] and the earth pressure calculation modes [2] of the retaining wall by model tests. However, it is noted that the retaining wall has displacements under the top load of the wall and the earth pressure. Moreover, the size and distribution of earth pressure of the retaining wall are closely related to the deformation of the retaining wall. Currently, the deformation properties and influencing factors of the retaining wall are still unclear, and the calculation mode of earth pressure lacks a reasonable theoretical basis and needs further study.

Many previous research studies have studied the deformation properties and influencing factors of the deformation of different types of retaining walls by using the finite element and finite difference numerical simulation methods [3-7]. The sheet pile wall is usually used when the lateral displacement of the wall needs to be restricted. Many factors may affect the wall deflection, including soil characteristics, wall height, loading behind the wall, and methods used during construction. The deflection and settlement of the cantilever sheet pile wall depend on soil properties, depth of 
the wall, and wall properties. The cantilever sheet pile walls were analyzed under surcharge loading for settlement and deflection through the pseudostatic approach by varying the seismic coefficients, embedded depth, soil-wall friction angle, type of soil, magnitude of surcharge, and distance from the top of the wall using finite difference-based program. The results showed that, by increasing the coefficient of horizontal seismic acceleration, the deflection and settlement of the wall increase; with an increase in the distance of surcharge from the top of the wall, both settlement and deflection decrease [8]. The influence of uniform surcharge load on the ground surface at a distance from the wall was analyzed for bending moment, earth pressure, deflection, and settlement behavior of cantilever sheet pile walls using the finite difference-based computer program, and it indicated that the mobilization of earth pressure takes place up to a greater depth with excavation depth greater than $60 \%$ of the total length of the wall and causes more settlement and deflection [9]. The FEM analyses were performed to investigate the effect of parameters on the anchored sheet pile wall and soil deformation and showed that multiple anchor levels were the most efficient way to reducing the deformation of the wall and the soil $[10,11]$.

A retaining wall with relieving platforms (relief shelves) is considered one of the special types of retaining walls. High cantilever retaining walls can be an economical solution by adding relieving platforms on the backfill side of the wall. The relieving platforms have the advantages of decreasing the lateral earth pressure and the deformation and increasing the overall stability of the retaining wall. Further studies in relation to model tests and finite element and finite difference numerical analysis were conducted for the retaining wall. For example, model tests were performed to determine the distribution of the earth pressure on the retaining wall with and without the relieving platform which is located at a depth of 0.4 times the wall height from the ground surface [12]. And model test results were compared with the analyzed results by the $2 \mathrm{D}$ finite element method and values driven from the theoretical equation. Model tests between the retaining wall with a relieving platform and the cantilever retaining wall were performed and showed that the reduction of the lateral earth pressure and deformation of the wall was indicated clearly on the retaining wall with a relieving platform $[13,14]$. And the overall stability was increased by the relieving platform. The influence of factors such as the location of the shelf, stiffness of the shelf, and shelf width on the behavior of the retaining wall with pressure relief shelves was studied by using STAAD Pro V8i software and presented a thorough comparative analysis of the retaining walls with no shelves, single shelf, two shelves, three shelves, and four shelves, with finding out the best location for providing shelves [15]. Some parametric studies were conducted by finite element analysis of retaining walls with relief shelves, and the effects of the length and number of shelves, shelf rigidity, and shelf position on the distribution of the lateral earth pressure, wall top movement, and acting maximum flexural moment of the wall were discussed. The reduced total active earth pressure due to the provisioning of shelves was depicted [16-18]. Numerical analyses were carried out for 15 cases varying with the type of retaining wall, length and location of the relieving platform, and the backfill type and showed that the lateral earth pressure of the retaining wall was considerably less than that of the cantilever wall and the lateral earth pressure was affected by the length and location of the relieving platform and the backfill type [19]. The optimal design conditions of the retaining wall with the relieving platform are proposed by evaluating the reduction effect of lateral earth pressure based on the numerical analysis of 40 cross sections by changing wall types, wall heights, shelf locations, and lengths. And the optimal location and length of a shelf are recommended [20]. A set of FEM analyses were used to explore the effect of the number of shelves, the shelf rigidity, and position on the lateral earth pressure distribution and top wall movement of retaining walls with relief shelves [21]. A three-dimensional finite difference numerical analysis was performed on the rigid nonyielding retaining wall retaining a dry cohesionless backfill with pressure relief shelves. A parametric study was also conducted to investigate the influence of width and position of relief shelves on the contact pressure under the base slab, the surface settlement profile of backfill, and the deflection of relief shelves [22].

However, currently, there is limited research conducted on the deformation and influencing factors of the sheet pile wall with a relieving platform. Tan et al. [23] presented the field testing as well as the three-dimensional numerical analysis on the anchored sheet pile quay wall with a spate pile-supported platform and showed that the lateral displacement of the sheet pile wall can be significantly reduced. Hu et al. [24] divided the sheet pile wall with a relieving platform into the loaded segment and anchored segment and developed a FEM numerical model to calculate the inner force and deformation of the sheet pile with the relieving platform, and the effectiveness of the calculation model was tested and confirmed by using the FEM model and analyzing the fielding monitoring data. Hu et al. [25] also deduced the analytical formula for the deformation of the retaining wall based on the elastic foundation beam method and analyzed the influences of the diameter and length of pile, the proportional coefficient of the foundation soil resistance coefficient, and the internal friction angle of the backfill on the structural deformation.

Most of the above research studies on retaining wall are conducted by using the finite element and finite difference numerical simulation methods, and limited research studies are conducted by using the scaled model tests. Although finite element and finite difference numerical simulation methods can establish the prototype retaining wall, it can calculate the influence of various factors on the force and deformation of the retaining wall. However, it often occurs that the influence factors are not considered comprehensively, or the calculation parameters, constitutive model, and boundary conditions are unreasonable, and the unreasonable results are obtained, which will have a large difference with the stress and deformation of the prototype retaining 
wall. In the scale model test, the displacement and stress parameters of the large size model are convenient to measure. Compared with finite element and finite difference numerical simulation methods, it can better reflect the stress and deformation of the prototype retaining wall and is more suitable for the study of the stress and deformation characteristics and influencing factors of the retaining wall.

In this paper, a retaining wall model with a similarity ratio of 7 was designed. This study used the model tests to analyze the main factors that may affect the deformation of the sheet pile wall with a relieving platform, including the width and buried depth of the unloading board, together with the presence or absence of the unloading board. In addition, the above research analysis was used to provide the theoretical underpinning to analyze and discuss the research results such as the selection of the design parameters, the development of the calculation modes of earth pressure, and deformation control of the retaining wall.

\section{Model Test Scheme}

2.1. Model Prototype and Similarity Ratio. Figure 1 shows the structure of the sheet pile wall with a relieving platform on a constructed landscape terrace. The retaining wall with a height of $12.0 \mathrm{~m}$ as shown was used as a prototype for model testing. The similarity ratio $(\lambda=7)$ is selected for this test.

2.2. Model Materials and Model Structure Size. The mediumcoarse sand was selected as the soil model material, and the physical and mechanical parameters of medium-coarse sand are shown in Table 1. Calculation was completed through the granule analysis test: $d_{60}=0.6 \mathrm{~mm}, d_{10}=0.21 \mathrm{~mm}$, $d_{30}=0.34 \mathrm{~mm}, C_{u}=2.86$, and $C_{c}=0.92$, and the mediumcoarse sand is in poor grade.

The structural material of the prototype retaining wall is reinforced concrete, and it is in an elastic state under normal working conditions. Owing to its characteristics of being easy to produce and simulate, steel was chosen as the model material for the retaining wall. A circular steel pipe pile was used to correspond to each part of the prototype structure, and the square steel pipe was applied in the pillar ribs. The channel steel and steel plates were applied in the unloading board.

The height of the prototype retaining wall is $12 \mathrm{~m}$, the pile spacing is $3 \mathrm{~m}$, and the height of the backfill is $12 \mathrm{~m}$. Accordingly, the width of the model test box is $2.0 \mathrm{~m}$, and 4 piles were simulated. The longitudinal length of the model test box is determined by the spatial dimension calculated using the sliding plane of the active earth pressure and passive earth pressure. The dimension of the model test box is shown in Figure 2, while the real figure of the model structure is illustrated in Figure 3.

The characteristic parameters of the retaining wall model structure are shown in Table 2.

\subsection{Loading Method and Displacement Measurement Systems.} The air pressure load was used to simulate the load on the top of the wall. The loading equipment is shown in Figure 4.

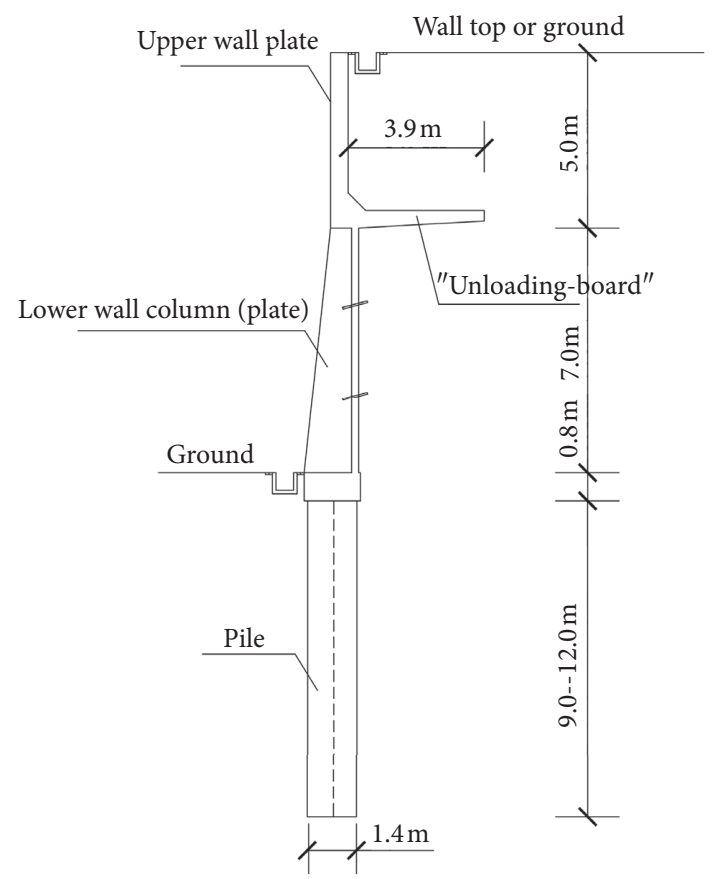

FIgURE 1: The cross section of the sheet pile wall with a relieving platform in a project.

The test was conducted among five levels from $10 \mathrm{kPa}$ to $50 \mathrm{kPa}$, with each level increasing by $10 \mathrm{kPa}$. The air pressure load has two advantages: (1) when the load is unloaded, the load transmission is consistent and continuous without impact; (2) its air pressure valve can be adjusted to maintain the load stability of each stage load. The magnitude of the change can be controlled within the range of $\pm 0.1 \mathrm{kPa}$.

By using the displacement measurement, the dial indicator with a range of $30 \mathrm{~mm}$ and an accuracy of $0.01 \mathrm{~mm}$ was selected. The dial indicator was fixed by using the magnetic gauge seat and ensuring that the extendable rods were tipped on the square steel pipe. It was found that the retaining wall was deflected with the increasing thickness of the sand layer. Moreover, the dial indicator could be used to measure the displacement of the retaining wall simultaneously. At the time of testing, there were also ten horizontal displacement measuring points on the rib pillar. The layout of displacement measurement points is shown in Figure 5. The real figure of the layout is shown in Figure 6.

2.4. Test Scheme. A total of 28-group model tests were conducted. They include one group test without the unloading board, 18 groups of comparison tests without imposed loads, and nine groups with imposed load comparison tests. Figure 7 shows the test process, and Table 3 shows the overview of the combination of tests. The credibility and validity of the self-made model of the retaining wall, the test instrument, and the test data had been verified in the previous research, and the accuracy of the measurement data of the retaining wall model had been verified by comparing them with the results from other theories [26]. 
TABle 1: Physical and mechanical property parameters of the medium-coarse sand.

\begin{tabular}{lcccccc}
\hline Items & $\begin{array}{c}\text { Deformation modulus } E \\
(\mathrm{MPa})\end{array}$ & $\begin{array}{c}\text { Poisson ratio } \\
\mu\end{array}$ & $\begin{array}{c}\text { Dry density } \rho_{d} \\
\left(\mathrm{~kg} / \mathrm{m}^{3}\right)\end{array}$ & $\begin{array}{c}\text { Internal friction } \\
\text { angle } \varphi\left({ }^{\circ}\right)\end{array}$ & $\begin{array}{c}\text { Specific } \\
\text { gravity }\end{array}$ & $\begin{array}{c}\text { Moisture content } \\
(\%)\end{array}$ \\
\hline $\begin{array}{l}\text { Medium-coarse } \\
\text { sand }\end{array}$ & 15 & 0.30 & 1591.0 & 35.8 & 2.653 & 12 \\
\hline
\end{tabular}

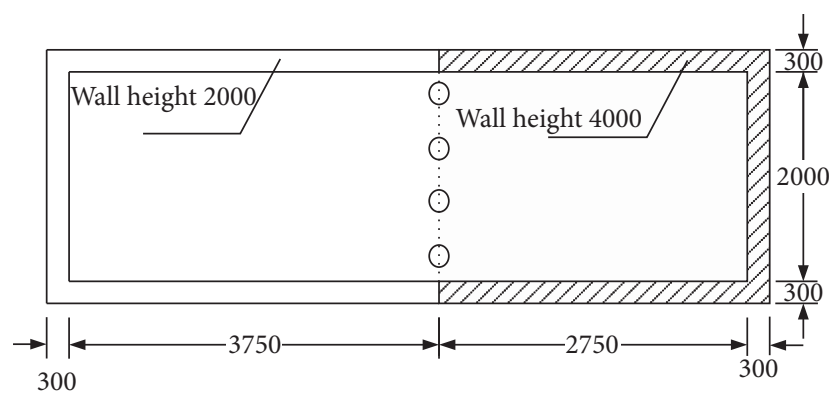

(a)

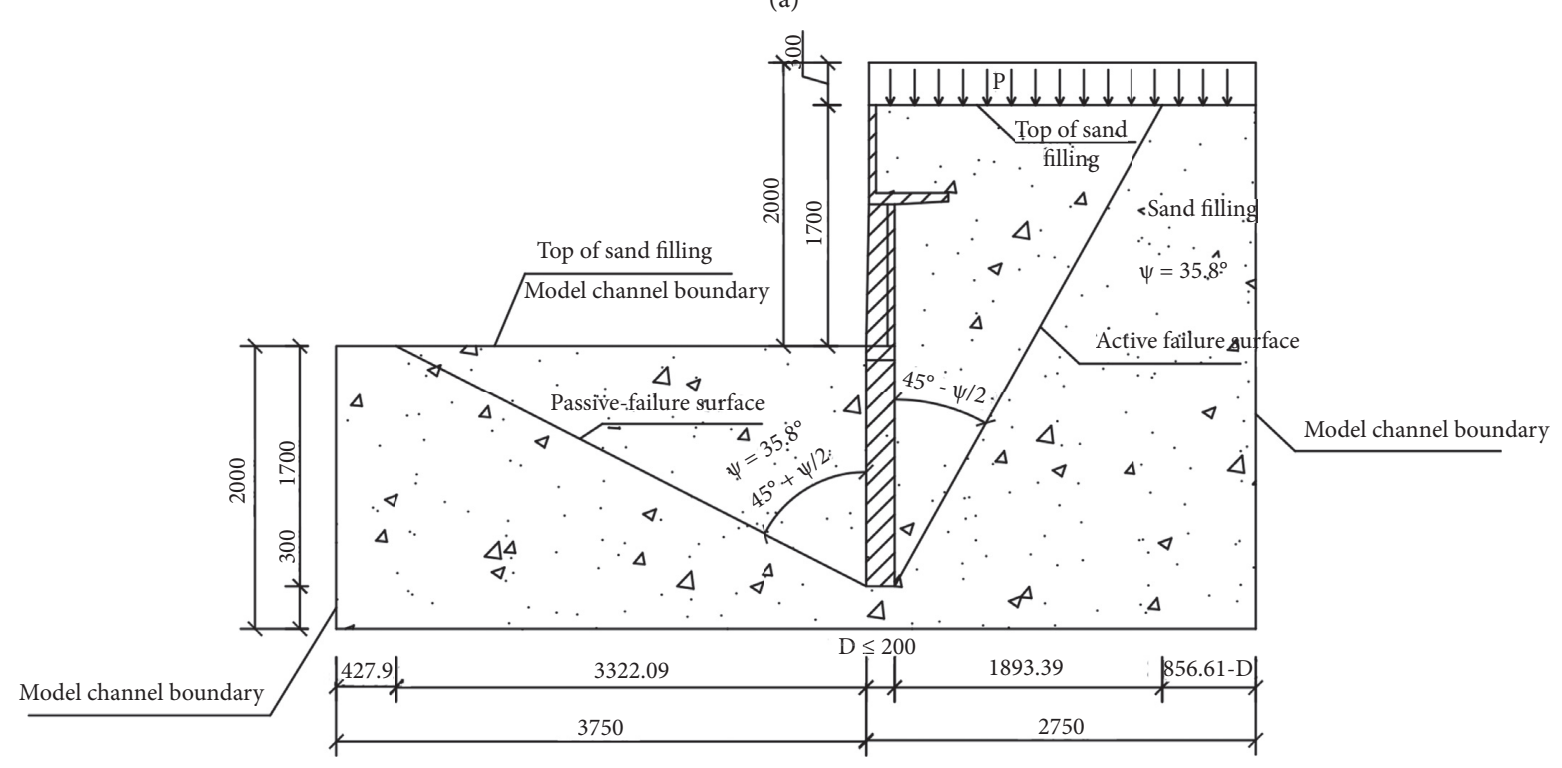

(b)

Figure 2: The dimension of the model test box. (a) Planar graph. (b) Profile drawing (the unit of the dimension is mm).

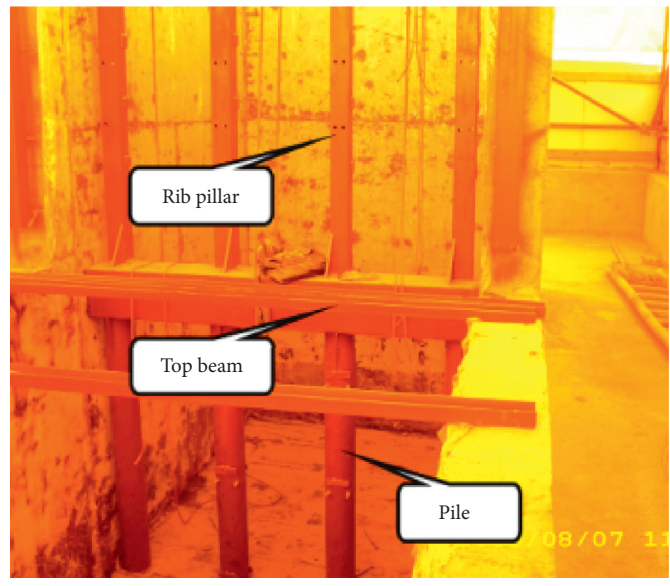

(a)

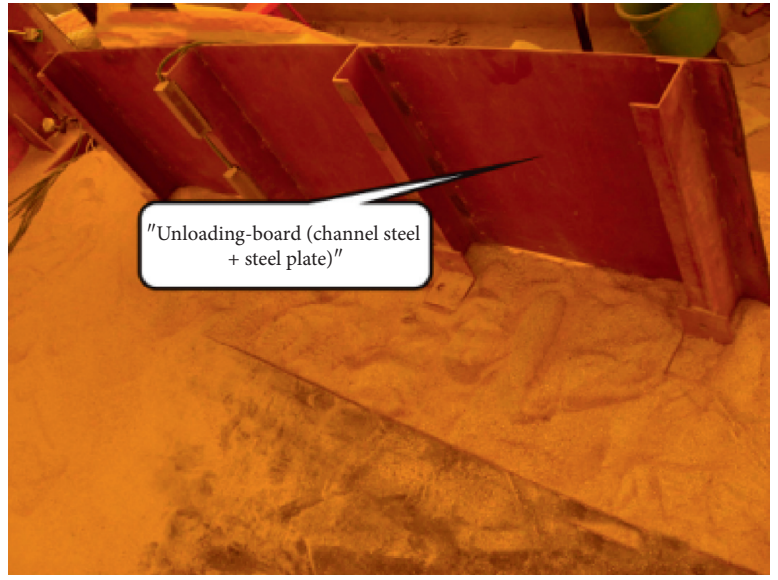

(b)

Figure 3: Real figure of the model structure. (a) Real figure 1. (b) Real figure 2. 
TABLE 2: The characteristic parameters of the retaining wall model structure [26].

\begin{tabular}{|c|c|c|c|c|c|c|}
\hline Components & $\begin{array}{l}\text { Required flexural } \\
\text { rigidity with unit } \\
\text { width }\left(\mathrm{N} \cdot \mathrm{m}^{2} / \mathrm{m}\right)\end{array}$ & $\begin{array}{l}\text { Calculation } \\
\text { width }(\mathrm{m})\end{array}$ & $\begin{array}{l}\text { Section } \\
\text { property of } \\
\text { materials }\end{array}$ & $\begin{array}{c}\text { Section } \\
\text { dimension of } \\
\text { materials }(\mathrm{mm}) \\
\end{array}$ & $\begin{array}{l}\text { Selected flexural } \\
\text { rigidity with unit } \\
\text { width }\left(\mathrm{N} \cdot \mathrm{m}^{2} / \mathrm{m}\right)\end{array}$ & Remarks \\
\hline Pile & $6.79 E 5$ & 0.6 & $\begin{array}{l}\text { Circular steel } \\
\text { pipe }\end{array}$ & $159 \times 5$ & $7.20 E 5$ & $\begin{array}{c}\text { Outer } \\
\text { diameter } \times \text { thickness }\end{array}$ \\
\hline Rib pillar & $1.94 E 5$ & 0.6 & $\begin{array}{l}\text { Square steel } \\
\text { pipe }\end{array}$ & $100 \times 2.5$ & $2.15 E 5$ & $\begin{array}{c}\text { Outer } \\
\text { diameter } \times \text { thickness }\end{array}$ \\
\hline $\begin{array}{l}\text { Unloading } \\
\text { board }\end{array}$ & $1.22 E 5$ & 0.6 & $\begin{array}{l}\text { Channel steel } \\
\text { and steel plate }\end{array}$ & $\begin{array}{c}\text { Channel } \\
10+5 \text { mm steel } \\
\text { plate }\end{array}$ & $1.02 E 5$ & $\begin{array}{c}\text { Small stiffness of channel } \\
\text { steel }\end{array}$ \\
\hline Top beam & $8.19 E 5$ & - & $\begin{array}{l}\text { Square steel } \\
\text { pipe }\end{array}$ & $250 \times 5$ & $9.81 E 5$ & - \\
\hline $\begin{array}{l}\text { Retaining } \\
\text { plate }\end{array}$ & $1.05 E 5$ & 0.6 & $\begin{array}{l}\text { Wooden } \\
\text { board }\end{array}$ & Thickness: 36 & $1.15 E 5$ & $\begin{array}{l}\text { Thickness: } 18 \mathrm{~mm} \text {; } \\
\text { overlapped wooden board }\end{array}$ \\
\hline
\end{tabular}

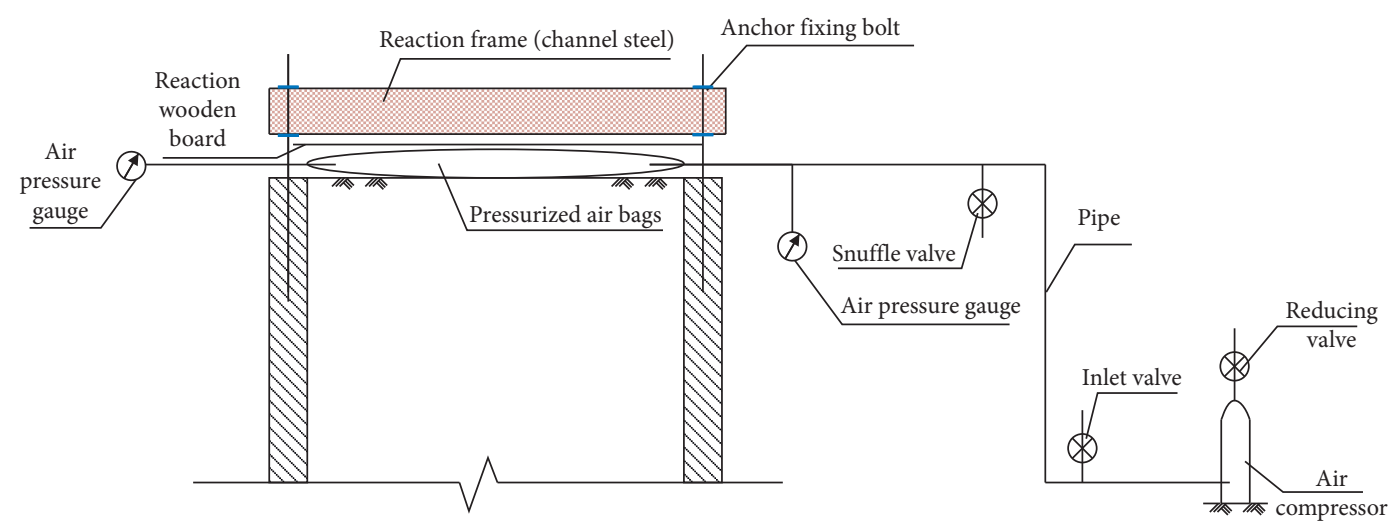

FIGURE 4: Air pressure loading equipment.

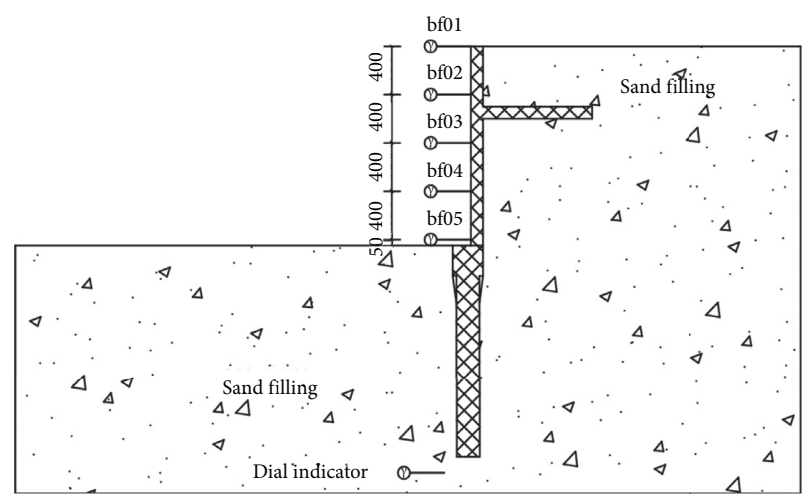

FIGURE 5: The layout of displacement measurement points of the retaining wall (unit: $\mathrm{mm}$ ).

\section{Analysis of Influencing Factors on the Deformation of Retaining Walls without External Load}

3.1. Comparison of the Measured Deformation on the Top of Rib Pillars and Numerical Simulation Results. Without the external load, when the buried depth of the unloading board $h$ is $0.6 \mathrm{~m}$ and $0.9 \mathrm{~m}$, the width of the unloading board $B$ is $0.5 \mathrm{~m}, 0.6 \mathrm{~m}$, and $0.8 \mathrm{~m}$, respectively. Table 4 shows the measured deformation on the top of the rib pillars and

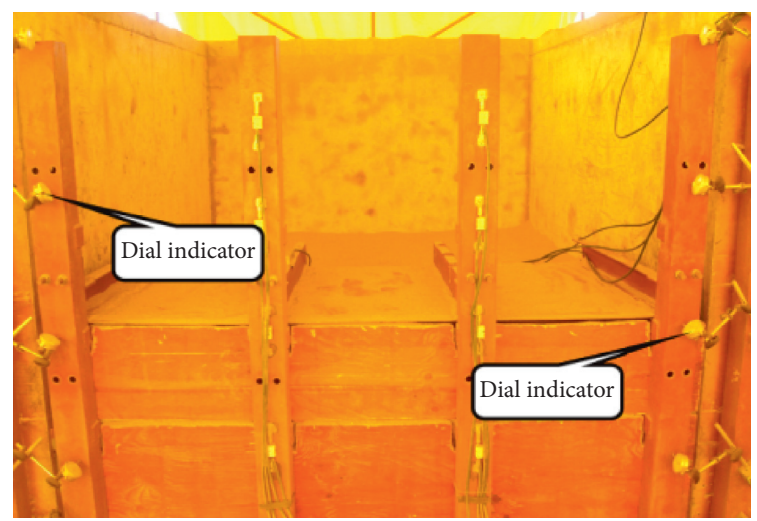

FIGURE 6: The real layout of the dial indicator.

numerical simulation results from the previous research [27]. The results of the width, buried depth, and calculation parameters of the unloading board are the same as the model test results [27]. When $h=0.6 \mathrm{~m}$, the margin of error between the measured deformation on the top of the rib pillars and the calculated value by the numerical simulation under three widths of the unloading board is about $1.53 \%$ to $4.67 \%$ (see Table 4). When $h=0.9 \mathrm{~m}$, the margin of error is about $0.17 \%$ to $7.66 \%$. The finding indicates that the measured deformation on the top of rib pillars in the model test is close 


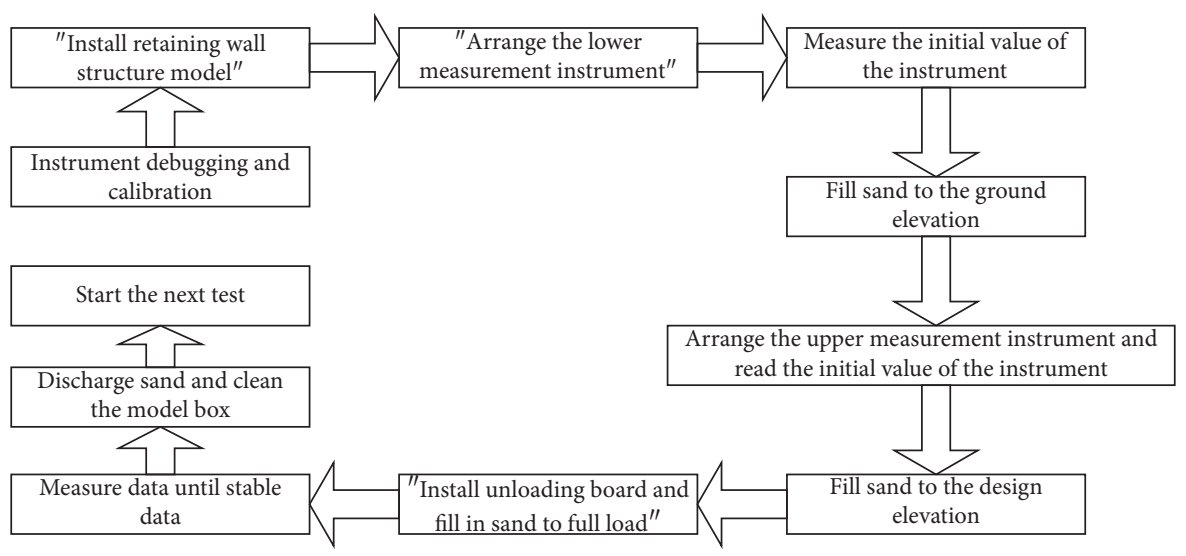

FIgURE 7: The flowchart of the test [26].

TABLe 3: The combined tests.

\begin{tabular}{lcccc}
\hline$B(\mathrm{~m})$ & $h(\mathrm{~m})$ & $\begin{array}{c}\text { Load at wall top } q \\
(\mathrm{kPa})\end{array}$ & Group numbers & Remark \\
\hline 0 & - & 0 & 1 & Without unloading board \\
$0.4,0.5,0.6,0.8,1.0$, and & $0.6,0.9$, and & 0 & $\begin{array}{c}\text { Combination of } B \text { and } h, 18 \\
\text { groups }\end{array}$ & Without external loading \\
1.2 & $\begin{array}{c}1.2 \\
0.4,0.6 \text {, and } 1.0\end{array}$ & $10 \sim 50$ & $\begin{array}{c}\text { Combination of } B \text { and } h, 9 \\
\text { groups }\end{array}$ & $\begin{array}{c}\text { Loading with each level increasing by } \\
10 \mathrm{kPa}\end{array}$ \\
\hline
\end{tabular}

TABLE 4: The comparison of measured deformation of rib pillars' top and numerical calculated results.

\begin{tabular}{|c|c|c|c|c|c|c|c|c|c|}
\hline & & $B=0.5 \mathrm{~m}$ & & & $B=0.6 \mathrm{~m}$ & & & $B=0.8 \mathrm{~m}$ & \\
\hline $\begin{array}{l}h \\
(\mathrm{~m})\end{array}$ & $\begin{array}{c}\text { Measured } \\
\text { value }(\mathrm{Mv}) \\
(\mathrm{mm})\end{array}$ & $\begin{array}{l}\text { Calculated } \\
\text { value }(\mathrm{Cv}) \\
\quad(\mathrm{mm})\end{array}$ & $\begin{array}{c}(\mathrm{Mv}-\mathrm{Cv}) / \\
\mathrm{Cv}(\%)\end{array}$ & $\begin{array}{c}\text { Measured } \\
\text { value }(\mathrm{Mv}) \\
(\mathrm{mm})\end{array}$ & $\begin{array}{c}\text { Calculated } \\
\text { value }(\mathrm{Cv}) \\
\quad(\mathrm{mm})\end{array}$ & $\begin{array}{c}(\mathrm{Mv}-\mathrm{Cv}) / \\
\mathrm{Cv}(\%)\end{array}$ & $\begin{array}{c}\text { Measured } \\
\text { value }(\mathrm{Mv}) \\
(\mathrm{mm})\end{array}$ & $\begin{array}{c}\text { Calculated } \\
\text { value }(\mathrm{Cv}) \\
(\mathrm{mm})\end{array}$ & $\begin{array}{c}(\mathrm{Mv}-\mathrm{Cv}) / \\
\mathrm{Cv}(\%)\end{array}$ \\
\hline 0.6 & 11.95 & 11.77 & 1.53 & 10.24 & 9.96 & 2. & 12.54 & 11.98 & 4.67 \\
\hline 0.9 & 10.30 & 10.06 & 2.39 & 8.71 & 8.09 & 7.66 & 11.67 & 10.69 & 0.17 \\
\hline
\end{tabular}

to the calculated values using the numerical simulation, which verifies the reliability of the model test.

\subsection{Effect of the Unloading Board Width on the Deformation of} Rib Pillars. Figures $8(\mathrm{a})-8(\mathrm{c})$ show the deformation of the rib pillars with the wall body at different board widths $B$, when there is no external load, and the buried depth of the unloading board $h=0.6 \mathrm{~m}, 0.9 \mathrm{~m}$, and $1.2 \mathrm{~m}$. The maximum deformation of the rib pillars at different board widths $B$ is shown in Table 5. It was found in Figure 8(a) and Table 5 that (a) when the buried depth $h=0.6 \mathrm{~m}$, the maximum deformation of rib pillars with different board widths $B$ is $S_{B=0.8}>S_{B=0.5}>S_{B=0.6}>S_{B=1.0}>S_{B=1.2}$, indicating that the buried depth $B=1.2 \mathrm{~m}$ is the most appropriate unloading board width, and (b) when the buried depth $h=0.6 \mathrm{~m}$, the maximum difference of the maximum deformation of rib pillars with different board widths is $35.9 \%$ of the average value. This finding indicates that, under this buried depth, the influences of unloading board width on the rib pillars deformation are smaller when $h=0.6 \mathrm{~m}$ than when $h=0.9 \mathrm{~m}$ and $h=1.2 \mathrm{~m}$.
Figure 8(b) and Table 5 show two findings: (a) when the buried depth $h=0.9 \mathrm{~m}$, the maximum deformation with different board widths $B$ is $S_{B=0.8}>S_{B=0.5}>S_{B=1.0}>S_{B=0.6}>S_{B=1.2}$, indicating that, under this buried depth, $B=1.2 \mathrm{~m}$ is the most appropriate board width, and (b) when the buried depth $h=0.9 \mathrm{~m}$, the maximum difference of the maximum deformation of rib pillars with different board's widths is $71.8 \%$ of the average value. This finding indicates that the width of the unloading board has a significant effect on the deformation of the rib pillars at this buried depth, and the effect is more significant when $h=0.6 \mathrm{~m}$ than when $h=0.9 \mathrm{~m}$.

There are also two findings as shown in Figure 8(c) and Table 5: (a) when the buried depth $h=1.2 \mathrm{~m}$, the maximum deformation with different board widths $B$ is $S_{B=0.5}>S_{B=0.4}>S_{B=0.6}>S_{B=1.0}>S_{B=1.2}$, indicating that, at this buried depth, $B=1.2 \mathrm{~m}$ is also the most appropriate board width, and(b) when the buried depth $h=1.2 \mathrm{~m}$, the maximum difference of the maximum deformation of rib pillars with different board's widths is $79.9 \%$ of the average value. This indicates that the width of the unloading board has the largest effect on the deformation of rib pillars, and the effect 


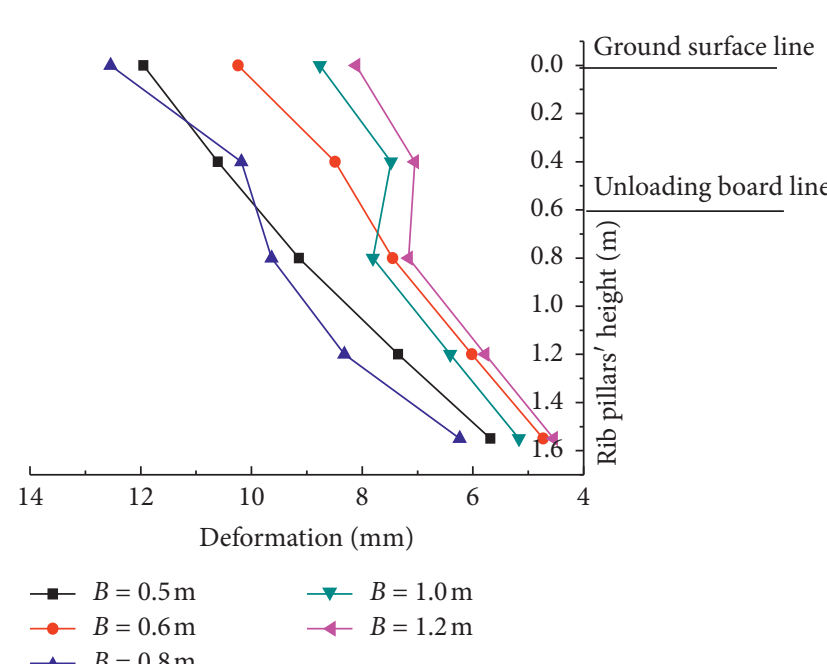

(a)

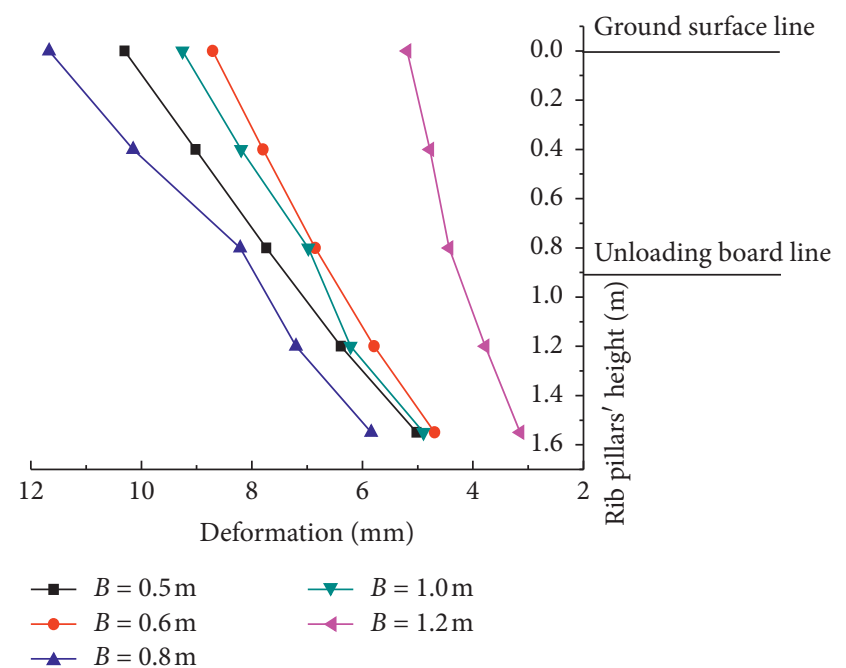

(b)

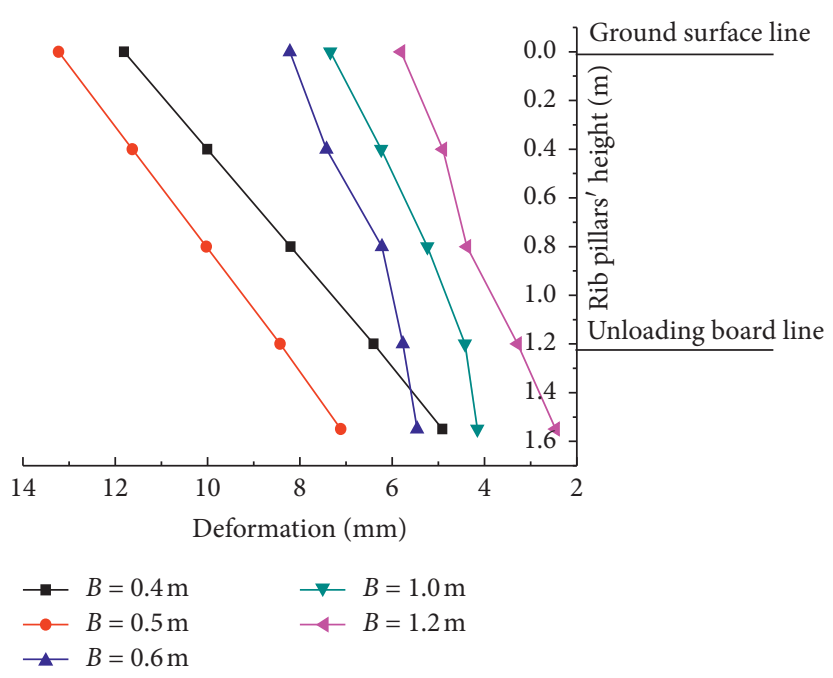

(c)

FIGURE 8: The variation curve of the deformation of rib pillars with the wall body at different widths $B$ of the unloading board: (a) $h=0.6 \mathrm{~m}$, (b) $h=0.9 \mathrm{~m}$, and (c) $h=1.2 \mathrm{~m}$.

TABLE 5: The maximum deformation of rib pillars at different widths $B$ of the unloading board.

\begin{tabular}{lccccccccc}
\hline$h(\mathrm{~m})$ & $B=0.4 \mathrm{~m}$ & $B=0.5 \mathrm{~m}$ & $B=0.6 \mathrm{~m}$ & $B=0.8 \mathrm{~m}$ & $B=1.0 \mathrm{~m}$ & $B=1.2 \mathrm{~m}$ & Maximum difference value $\Delta$ & Average value $\mu$ & $\Delta / \mu$ \\
\hline 0.6 & - & $11.95 \mathrm{~mm}$ & $10.24 \mathrm{~mm}$ & $12.54 \mathrm{~mm}$ & $8.77 \mathrm{~mm}$ & $9.12 \mathrm{~mm}$ & 3.78 & 10.53 & 35.9 \\
0.9 & - & $10.30 \mathrm{~mm}$ & $8.71 \mathrm{~mm}$ & $11.67 \mathrm{~mm}$ & $9.26 \mathrm{~mm}$ & $5.19 \mathrm{~mm}$ & 6.48 & 7.03 & 71.8 \\
1.2 & $11.81 \mathrm{~mm}$ & $13.23 \mathrm{~mm}$ & $8.23 \mathrm{~mm}$ & - & $7.34 \mathrm{~mm}$ & $5.81 \mathrm{~mm}$ & 7.42 & 9.28 & 79.9 \\
\hline
\end{tabular}

is more significant when $h=1.2 \mathrm{~m}$ than when $h=0.6 \mathrm{~m}$ and $h=0.9 \mathrm{~m}$.

In summary, when the buried depth $h$ is constant, the board width $B$ has a significant effect on the deformation of the rib pillars. Moreover, the effect becomes more significant as the buried depth $h$ increases. When the buried depth $h$ is constant, the width of the unloading board $B=1.2 \mathrm{~m}$ ( 0.7 times the wall height) is most suitable if the displacement is the smallest number. The analysis of the impact of the board width on the deformation of the rib pillars shows that when the width of the unloading board is shorter, the deformation of the sheet pile wall with a relieving platform tends to be similar to the horizontal deformation of the cantilever sheet pile wall. Moreover, the deformations of the retaining wall as well as the rib pillars become larger. Within a certain range of the widths of the unloading board, the reverse bending moment is correlated with the deformation of the structure. The frictional resistance from the surrounding earth on the board imposes a binding effect on the deformation of the retaining wall, resulting in a relatively smaller deformation of the rib pillars. 
3.3. Effect of Buried Depth of the Unloading Board on the Deformation of Rib Pillars. Figures 9(a)-9(c) show when there is no external load and the width of the unloading board $B=0.5 \mathrm{~m}, 0.6 \mathrm{~m}$, and $1.2 \mathrm{~m}$, the deformation of the rib pillars changes with the wall body at different buried depths $h$. Table 6 shows the maximum deformation of the rib pillars at different buried depths $h$.

Two findings are shown in Figure 9(a) and Table 6: (a) When $B=0.5 \mathrm{~m}$, the maximum deformation of the rib pillars at different buried depths is $S_{h=1.2}>S_{h=0.6}>S_{h=0.9}$. When the buried depth $h=0.9 \mathrm{~m}$, the deformation of the rib pillars is the minimum, indicating that $h=0.9 \mathrm{~m}$ is a reasonable buried depth of the unloading board at this board width. (b) When $B=0.5 \mathrm{~m}$, the maximum difference of the maximum deformation of rib pillars with different board widths is $24.7 \%$ of the average value. It indicates that, at this board width $(B=0.5 \mathrm{~m})$, the effect of buried depth on the deformation of the rib pillars is much smaller than the width of the unloading board $(B=1.2 \mathrm{~m})$.

Figure 9(b) and Table 6 show the following: (a) when $B=0.6 \mathrm{~m}$, the maximum deformation of the rib pillars at different buried depths is $S_{h=0.6}>S_{h=0.9}>S_{h=1.2}$. When $h=0.9 \mathrm{~m}$ and $h=1.2 \mathrm{~m}$, the maximum deformation of the rib pillars is smaller and closer, indicating that, at this board width, the buried depth $h=0.9 \mathrm{~m}$ is reasonable, and too large buried depth fails to effectively reduce the deformation of the rib pillars. (b) When $B=0.6 \mathrm{~m}$, the maximum difference of the maximum deformation of rib pillars at different buried depths is $22.3 \%$ of the average value. This finding indicates that, at this board width, the effect of buried depth on the deformation of the rib pillars is relatively small.

It was also found in Figure 9(c) and Table 6 that (a) when $B=1.2 \mathrm{~m}$, the maximum deformation of the rib pillars at different buried depths is $S_{h=0.6}>S_{h=1.2}>S_{h=0.9}$; (b) when $B=1.2 \mathrm{~m}$, the maximum difference of the maximum deformation of rib pillars at different buried depths is $58.6 \%$ of the average value. This finding shows that, at this width of the slab, the effect of buried depth on the deformation of the rib pillars is significant; (c) when $B=1.2 \mathrm{~m}$ and $h=0.9 \mathrm{~m}$, the maximum deformation of the rib pillars is smallest, indicating that, at this board width, $h=0.9 \mathrm{~m}$ is a reasonable buried depth of the unloading board.

In summary, this section has two following major findings:(a) when $B=0.5$ and $1.2 \mathrm{~m}$ and the buried depth $h=0.9 \mathrm{~m}$, the maximum deformation of rib pillars is minimal, and $h=0.9 \mathrm{~m}$ (0.53 times the wall height) is a reasonable buried depth of the unloading board, and when $B=0.6 \mathrm{~m}$, the maximum deformation of rib pillars is smaller and closer at the buried depth $h=0.9 \mathrm{~m}$ and $h=1.2 \mathrm{~m}$, and $h=0.9 \mathrm{~m}(0.53$ times the wall height) is also a more reasonable buried depth. Too large buried depth fails to effectively reduce the deformation of rib pillars. The analysis of the test results shows when the unloading board is set at a reasonable depth, the effect on the deformation of the retaining wall is limited. Moreover, when the unloading board is set at a low location (with a large buried depth), the deformation of the retaining wall structure tends to be similar to the horizontal deformation of the cantilever sheet pile wall, which cannot effectively reduce the deformation of the retaining wall.
3.4. Effect of the Presence or Absence of the Unloading Board on the Deformation of Rib Pillars. In Tables 5 and 6, it shows that, without the external load and with the combination of different widths and buried depths of the unloading board, the maximum deformation of rib pillars is $5.19 \mathrm{~mm}$. The value is the smallest when $B=1.2 \mathrm{~m}$ and $h=0.9 \mathrm{~m}$. The maximum deformation of the rib pillars is $13.23 \mathrm{~mm}$ and the largest when $B=0.5 \mathrm{~m}$ and $h=1.2 \mathrm{~m}$. These two extremes are compared with the maximum deformation of rib pillars without the unloading board (see Table 7).

Table 7 shows the following three major findings:

(1) The deformation value on the top of rib pillars without the unloading board is $22.16 \mathrm{~mm}$, and the ratio of this value to the height of the rib pillar is $22.16 / 1700 \times 100 \%=1.30 \%$. This does not meet the provisions of the specification for "TB 10025-2006, J 127-2006: Code for Design on Retaining Structures of Railway Subgrade" (Ministry of Railways of the People's Republic of China, 2006) that the top displacement of the pile sheet wall is less than $1 \%$ of the length of the cantilever sheet pile. The retaining wall has been considered damaged, that is, under this condition, the structure of the retaining wall without the unloading board is unreasonable.

(2) The maximum deformation of rib pillars at $B=0.5 \mathrm{~m}$ and $h=1.2 \mathrm{~m}$ is $40.3 \%$ less than the value when the unloading board is absent. The maximum deformation of rib pillars at $B=1.2 \mathrm{~m}$ and $h=0.9 \mathrm{~m}$ is also $76.6 \%$ less of the value when the unloading board is absent. The finding shows the setting of the unloading board has a significant effect on inhibiting the deformation of rib pillars.

(3) According to the minimum and maximum value of the maximum deformation of the rib pillars in the model tests, the ratio of the maximum deformation of the rib pillars to the height of the rib pillars is $0.31 \%$ to $0.78 \%$. The value is less than $1 \%$ of the length in the specification for "TB 10025-2006, J 127-2006: Code for Design on Retaining Structures of Railway Subgrade" (Ministry of Railways of the People's Republic of China, 2006) of the top displacement of the pile sheet wall, that is, the displacement of the retaining wall after the installation of the unloading board is within the safety limits, which also validates and confirms that the installation of the unloading board makes the retaining wall structure more reasonable.

\section{Analysis of Influencing Factors on the Deformation of Retaining Walls under External Load}

4.1. Effect of the Unloading Board Width on the Deformation of Rib Pillars. When the buried depth $h=0.6 \mathrm{~m}$ and the external load $p=10 \mathrm{kPa}$ and $p=50 \mathrm{kPa}$, the deformation of the rib pillars changes with the wall body when the unloading board widths $B$ is different (see Figure 10). With the buried depth $h=0.6 \mathrm{~m}$ and the same board width, the deformation 


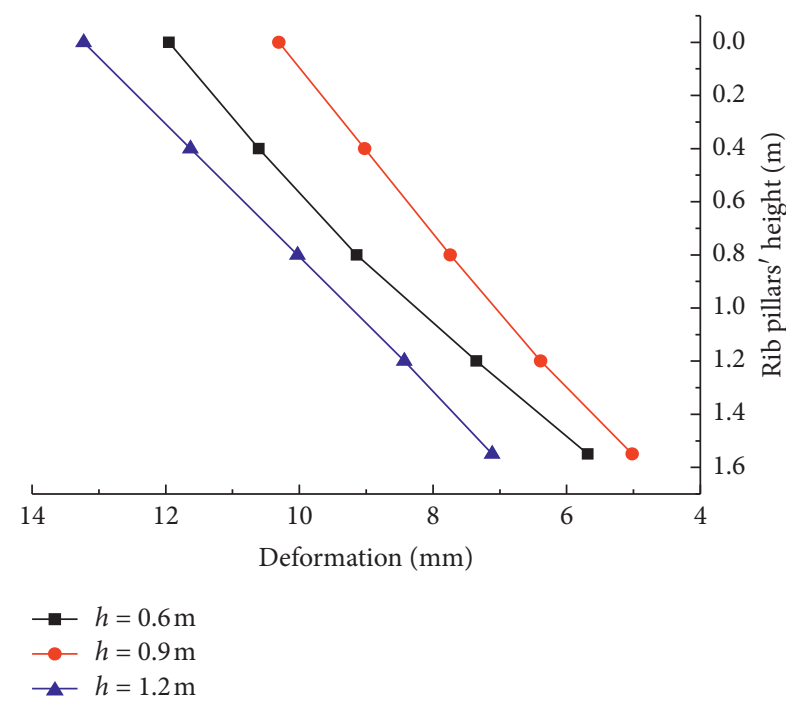

(a)

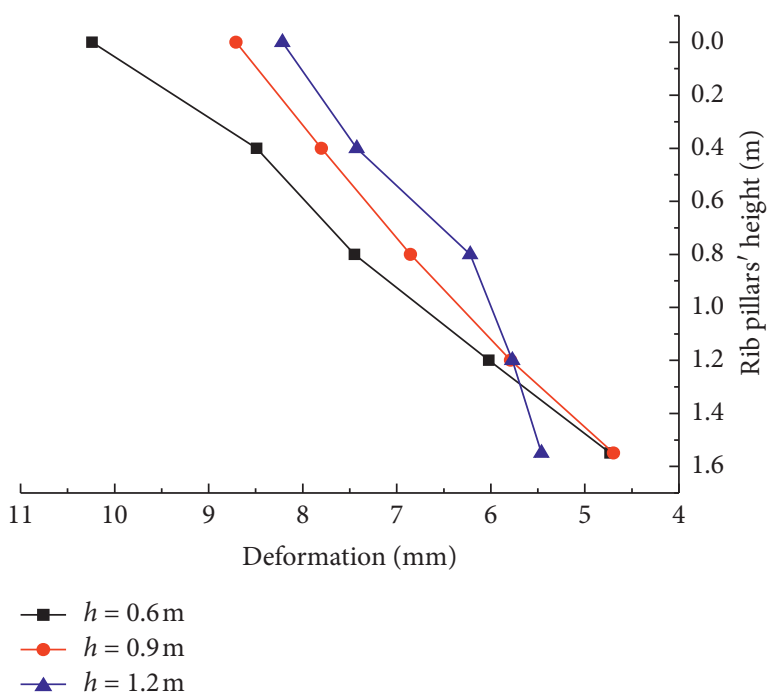

(b)

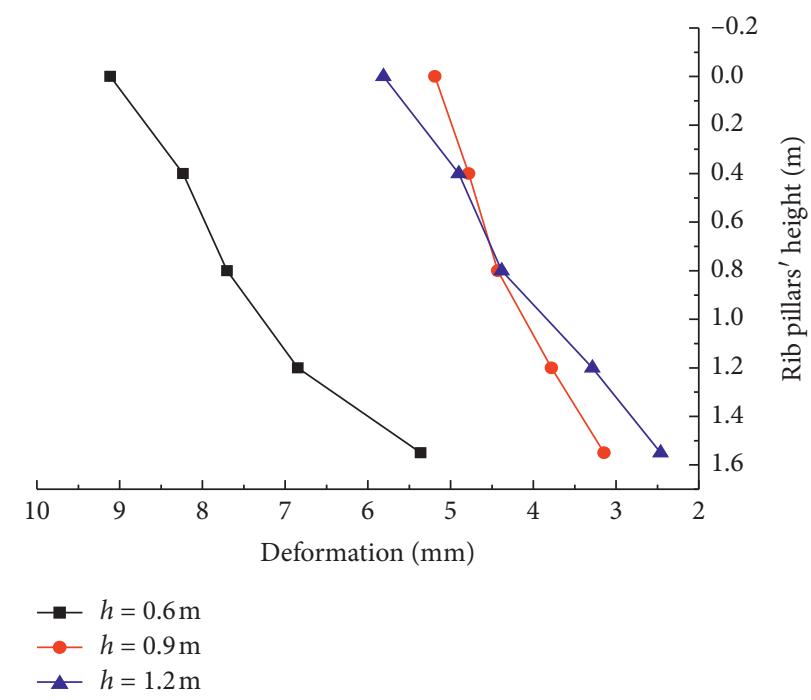

(c)

Figure 9: The variation curve of the deformation of rib pillars with the wall body at different buried depths $h$. (a) $B=0.5 \mathrm{~m}$, (b) $B=0.6 \mathrm{~m}$, and (c) $B=1.2 \mathrm{~m}$.

TABle 6: The maximum deformation of rib pillars at different buried depths $h$.

\begin{tabular}{lcccccc}
\hline$B(\mathrm{~m})$ & $h=0.6 \mathrm{~m}$ & $h=0.9 \mathrm{~m}$ & $h=1.2 \mathrm{~m}$ & Maximum difference value $\Delta(\mathrm{mm})$ & Average value $\mu(\mathrm{mm})$ & $\Delta / \mu(\%)$ \\
\hline 0.5 & $11.95 \mathrm{~m}$ & $10.31 \mathrm{~m}$ & $13.23 \mathrm{~m}$ & 2.92 & 11.83 & 24.7 \\
0.6 & $10.24 \mathrm{~m}$ & $8.71 \mathrm{~mm}$ & $8.22 \mathrm{~mm}$ & 2.02 & 9.06 & 22.3 \\
1.2 & $9.21 \mathrm{~mm}$ & $5.19 \mathrm{~mm}$ & $5.81 \mathrm{~mm}$ & 3.93 & 6.71 \\
\hline
\end{tabular}

of rib pillars (at the same height of the retaining wall) increases significantly when the external load increases. Moreover, the deformation of rib pillars (at the same height of the retaining wall) under each load is $S_{B=0.4}>S_{B=1.0}>S_{\mathrm{B}=0.6}$. When the buried depth $h$ is small and $B=0.6 \mathrm{~m}$, the deformation of rib pillars is minimal, and overlength board width fails to effectively reduce the deformation of rib pillars. This finding is consistent with the conditions of no external load. Finally, when $B=0.4 \mathrm{~m}$ (too short), the deformation of the rib pillars is large, indicating too small board width is not suitable either, and the reasonable board width is $B=0.6 \mathrm{~m}$ ( 0.35 times the wall height).

Figure 11 shows that the deformation of rib pillars at different board widths changes to align with the wall body, when the buried depth $h=0.9 \mathrm{~m}$ and the external load $p=10 \mathrm{kPa}$ and $p=50 \mathrm{kPa}$. When $h=0.9 \mathrm{~m}$, the deformation of rib pillars at the same height of the retaining wall under each load is $S_{B=0.4}>S_{B=0.6}>S_{B=1.0}$. When the buried depth $h$ 
TABLE 7: Comparison of the maximum deformation of rib pillars with or without the unloading board.

\begin{tabular}{lccc}
\hline Unloading board setting condition & $\begin{array}{c}\text { The maximum deformation } S_{\max } \\
(\mathrm{mm})\end{array}$ & $\begin{array}{c}\text { Decreasing deformation } \\
(\mathrm{mm})\end{array}$ & $\begin{array}{c}\text { Decreasing the percent of the } \\
\text { deformation }(\%)\end{array}$ \\
\hline $\begin{array}{l}\text { Without unloading board }(B=0) \\
\text { With unloading board }(B=1.2 \mathrm{~m},\end{array}$ & 22.16 & - & - \\
$\begin{array}{l}h=0.9 \mathrm{~m}) \\
\begin{array}{l}\text { With unloading board }(B=0.5 \mathrm{~m}, \\
h=1.2 \mathrm{~m})\end{array}\end{array}$ & 5.19 & 16.97 & 76.6 \\
\end{tabular}

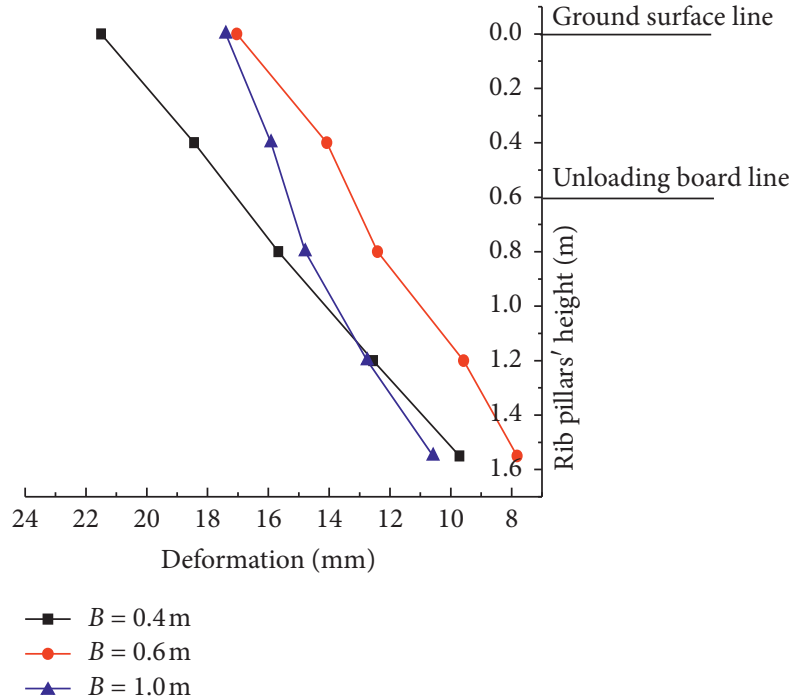

(a)

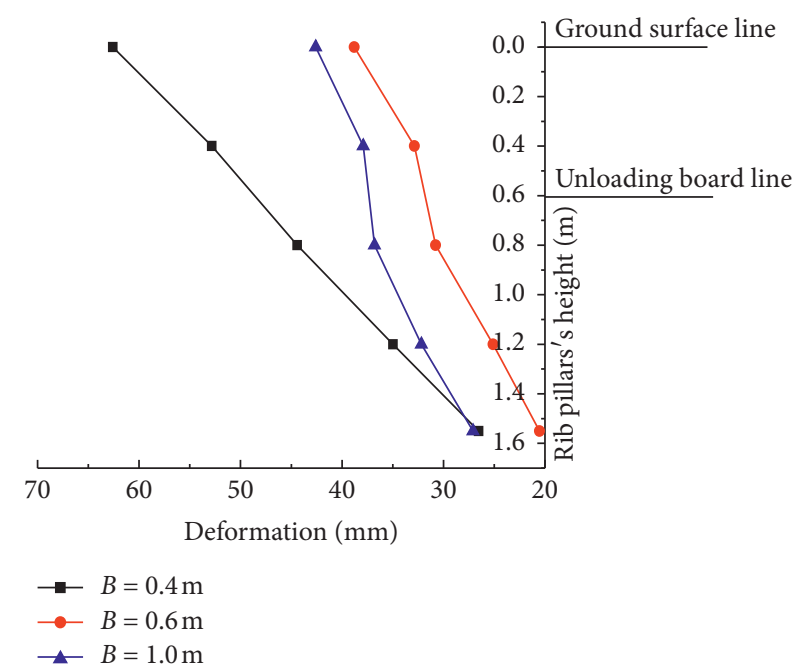

(b)

FiguRE 10: The variation curve of the deformation of rib pillars with the wall body at the external load: (a) $h=0.6 \mathrm{~m}(p=10 \mathrm{kPa})$ and (b) $h=0.6 \mathrm{~m}$ $(p=50 \mathrm{kPa})$.

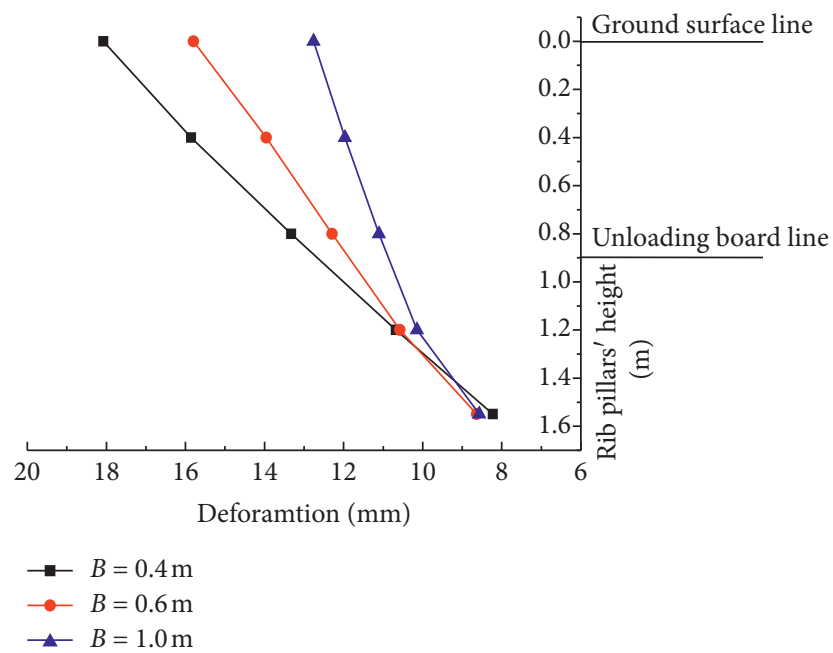

(a)

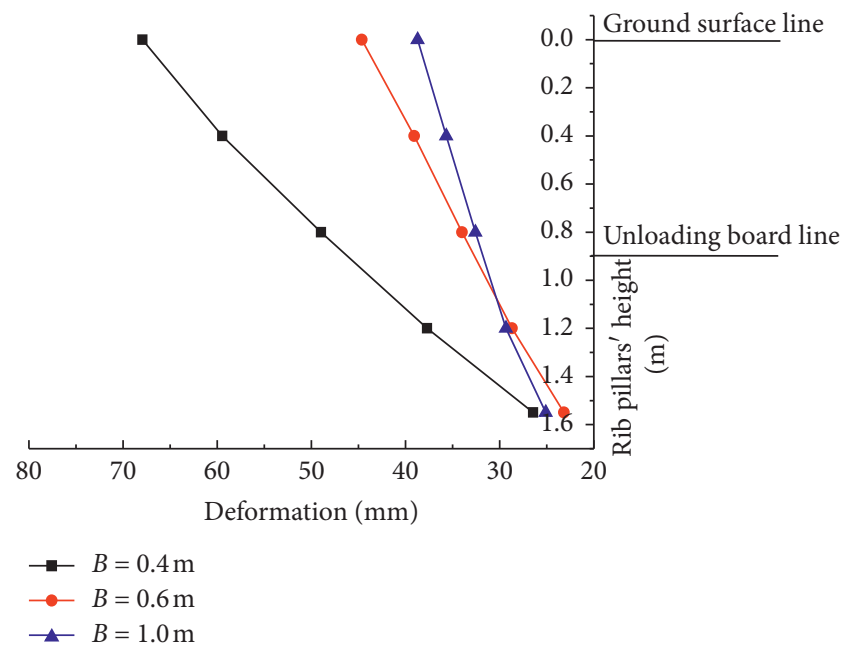

(b)

FIGURE 11: The variation curve of the deformation of rib pillars with the wall body at the external load: (a) $h=0.9 \mathrm{~m}(p=10 \mathrm{kPa})$ and (b) $h=0.9 \mathrm{~m}$ $(p=50 \mathrm{kPa})$.

is moderate, the deformation of rib pillars decreases as the board width increases. At the buried depth $h=0.9 \mathrm{~m}$, over short board width is inappropriate, and the reasonable board width should be $B=1.0 \mathrm{~m}$.
Figure 12 shows the variation of rib pillars' deformation with the wall body at different board widths $B$, when the buried depth $h=1.2 \mathrm{~m}$ and the external load $p=10 \mathrm{kPa}$ and $p=50 \mathrm{kPa}$. It was found when $h=1.2 \mathrm{~m}$, the deformation of 


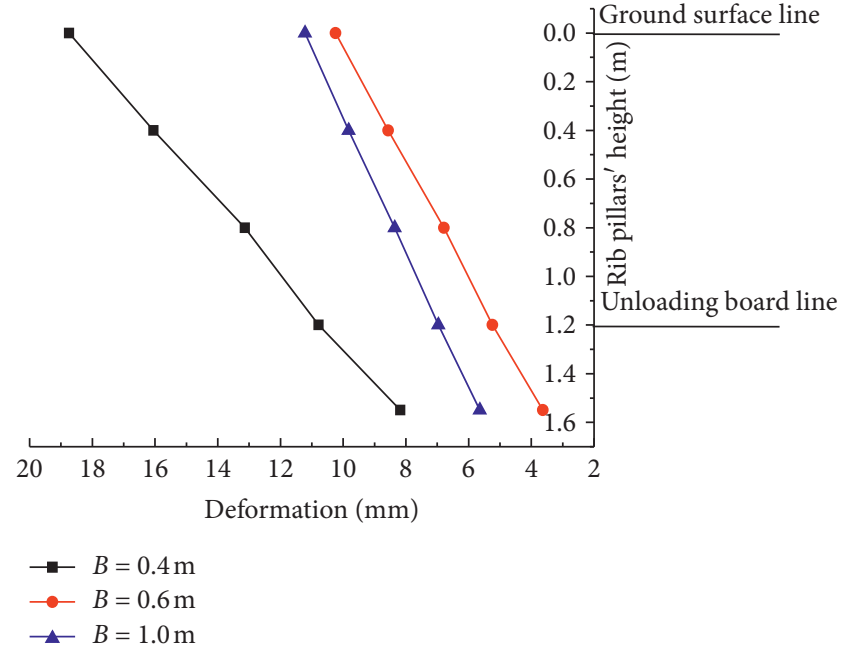

(a)

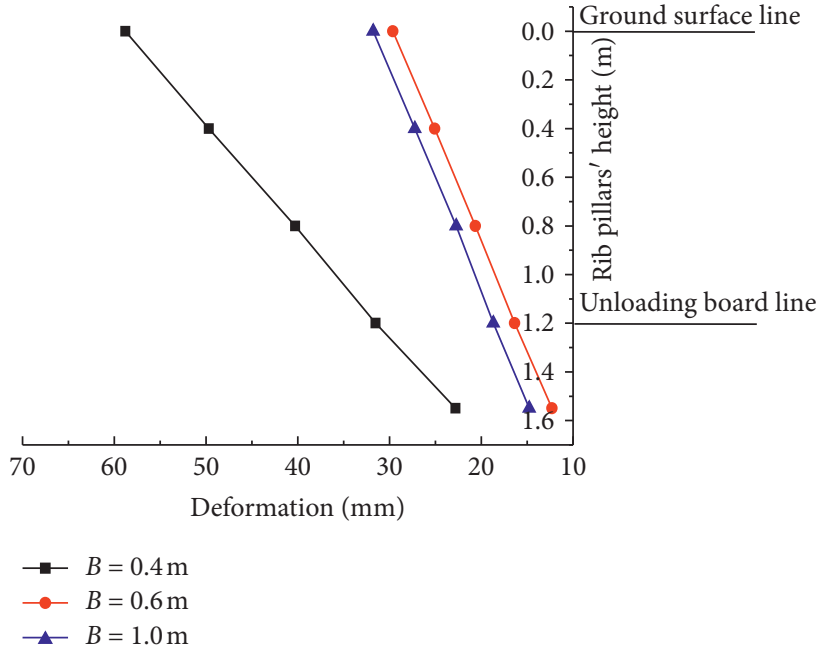

(b)

Figure 12: The variation curve of the deformation of rib pillars with the wall body at the external load: (a) $h=1.2 \mathrm{~m}(p=10 \mathrm{kPa})$ and (b) $h=1.2 \mathrm{~m}$ $(p=50 \mathrm{kPa})$.

rib pillars at the same height of the retaining wall under each load is $S_{B=0.4}>S_{B=1.0}>S_{B=0.6}$, same as when $h=0.6 \mathrm{~m}$. It was also found when $h=1.2 \mathrm{~m}$ (relatively deep) and $B=0.6 \mathrm{~m}$, the deformation of rib pillars is the minimum, and overlength board width fails to reduce the deformation effectively. When $B=0.4 \mathrm{~m}$ (too short), the deformation of rib pillars is large, indicating that the unloading board should not be too short either. The reasonable board width is $B=0.6 \mathrm{~m}$ (0.35 times the wall height).

4.2. Effect of Buried Depth of the Unloading Board on the Deformation of Rib Pillars. Figure 13 shows the variation of rib pillars' deformation with the wall body at different buried depths $h$, when the board width $B=0.4 \mathrm{~m}$ and the external load $p=10 \mathrm{kPa}-50 \mathrm{kPa}$. It can be found in Figure 13 that (a) when $B=0.4 \mathrm{~m}$, the variation with the buried depth has less effect on the deformation of the rib pillars under various loads, and (b) when $B=0.4 \mathrm{~m}$ (relatively small) and $p \leq 30 \mathrm{kPa}$ (relatively small), the deformation of rib pillars is the minimum at $h=0.9 \mathrm{~m}$ (moderate). When $B=0.4 \mathrm{~m}$ (relatively small) and $p \geq 30 \mathrm{kPa}$ (relatively large), the deformation of rib pillars is the minimum at $h=1.2 \mathrm{~m}$ (relatively large).

Figure 14 shows the variation of rib pillars' deformation with the wall body at different buried depths $h$ when the board width $B=0.6 \mathrm{~m}$ and the external load $p=10 \mathrm{kPa}-50 \mathrm{kPa}$. It was found in Figure 14 that when $B=0.6 \mathrm{~m}$, the variation with the buried depth has a relatively large influence on the deformation of rib pillars under various loads. Moreover, when $B=0.6 \mathrm{~m}$ and $h \leq 0.9 \mathrm{~m}$, the deformation of rib pillars under various loads increases with the increase of buried depth, but to a small extent. When $B=0.6 \mathrm{~m}$ and $h \geq 0.9 \mathrm{~m}$, the deformation of rib pillars under various loads decreases when the buried depth increases, to a relatively large extent. Larger buried depth is more reasonable when the board width $B=0.6 \mathrm{~m}$.

Figure 15 shows the variation of rib pillars' deformation with the wall body at different buried depths $h$ when the board width $B=1.0 \mathrm{~m}$ and the external load $p=10$ $\mathrm{kPa}-50 \mathrm{kPa}$. In Figure 15 , it was found when $B=1.0 \mathrm{~m}$, the deformation of rib pillars under various loads decreases when the buried depth $h$ increases. When $h \geq 0.9 \mathrm{~m}$, the variation with the buried depth under various loads has a 

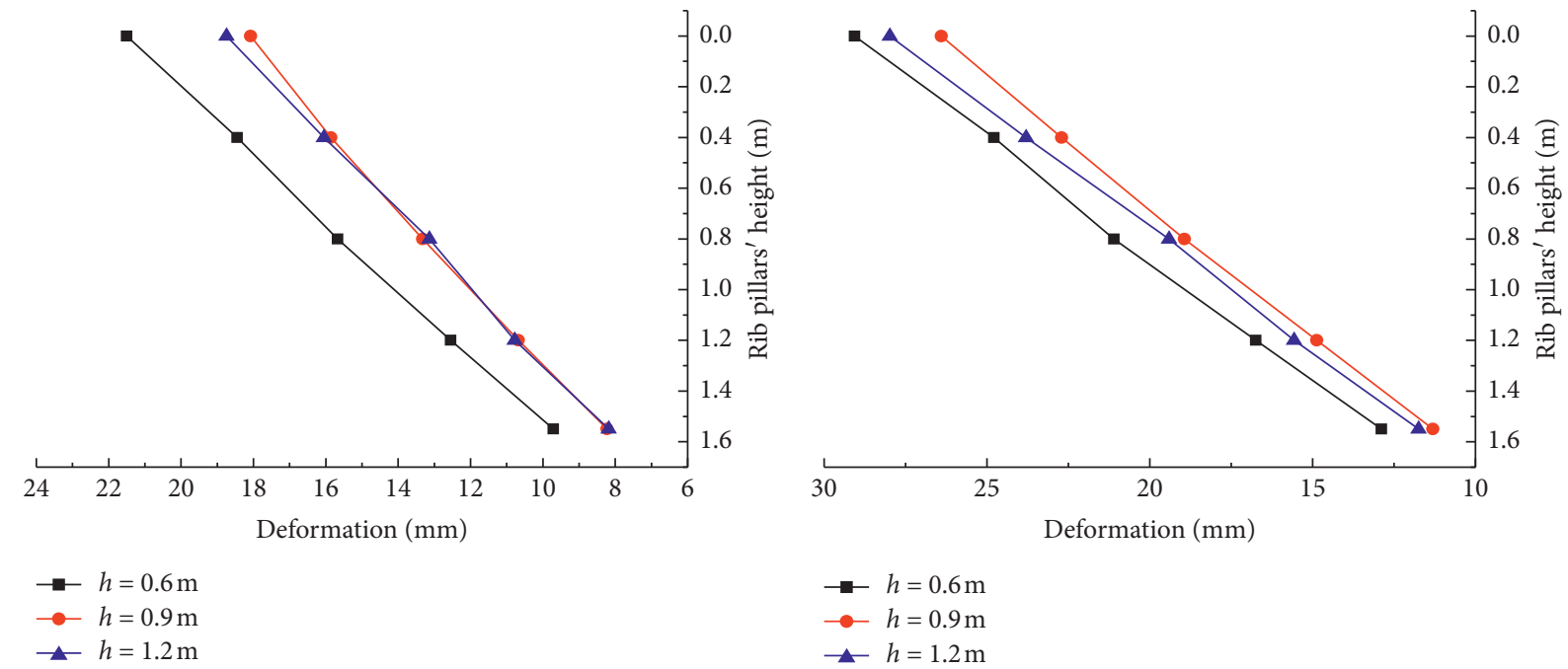

(a)

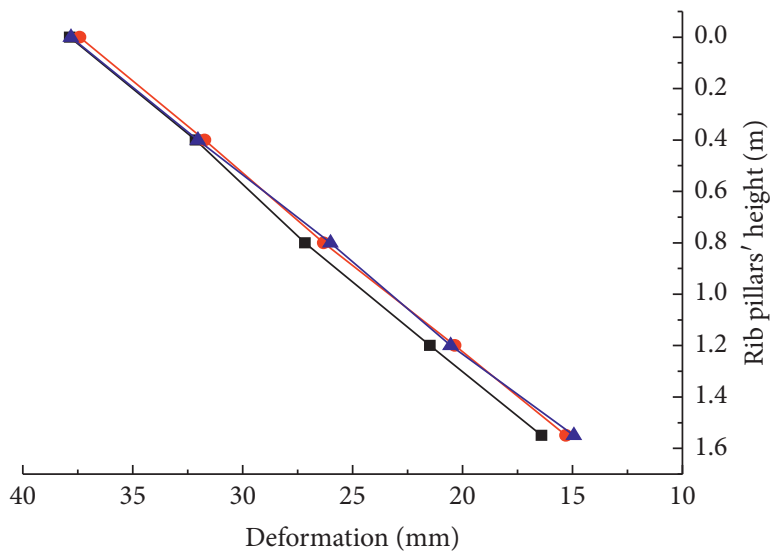

(b)

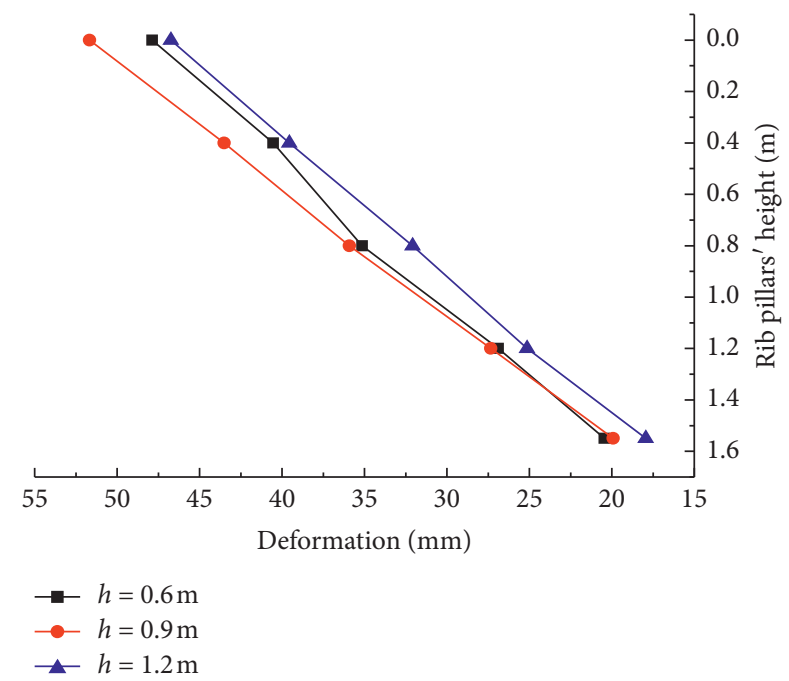

(c)

(d)

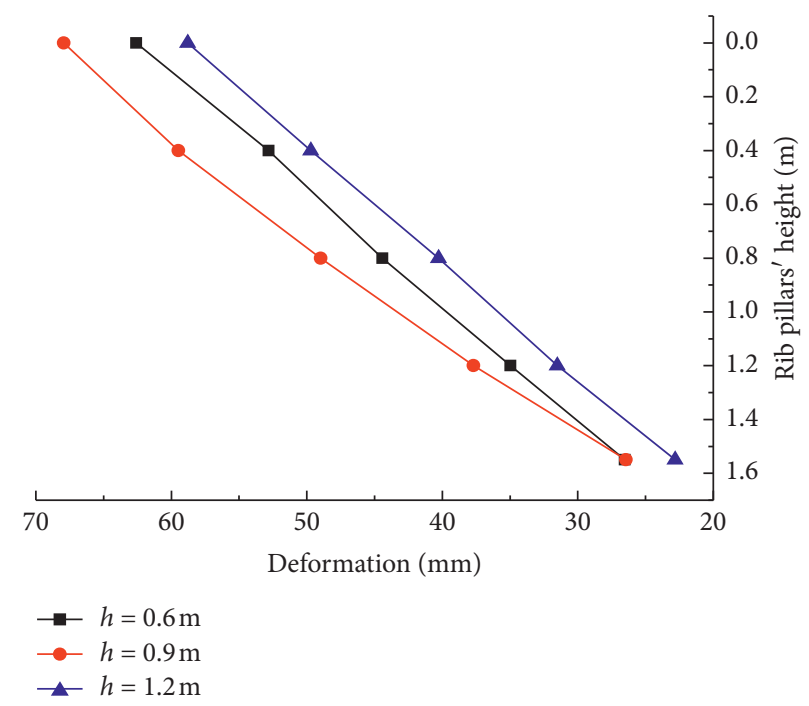

(e)

Figure 13: The variation curve of the deformation of rib pillars with the wall body when $B=0.4 \mathrm{~m}$ at the external load: (a) $B=0.4 \mathrm{~m}$ $(p=10 \mathrm{kPa}),(\mathrm{b}) B=0.4 \mathrm{~m}(p=20 \mathrm{kPa}),(\mathrm{c}) B=0.4 \mathrm{~m}(p=30 \mathrm{kPa}),(\mathrm{d}) B=0.4 \mathrm{~m}(p=40 \mathrm{kPa})$, and (e) $B=0.4 \mathrm{~m}(p=50 \mathrm{kPa})$. 

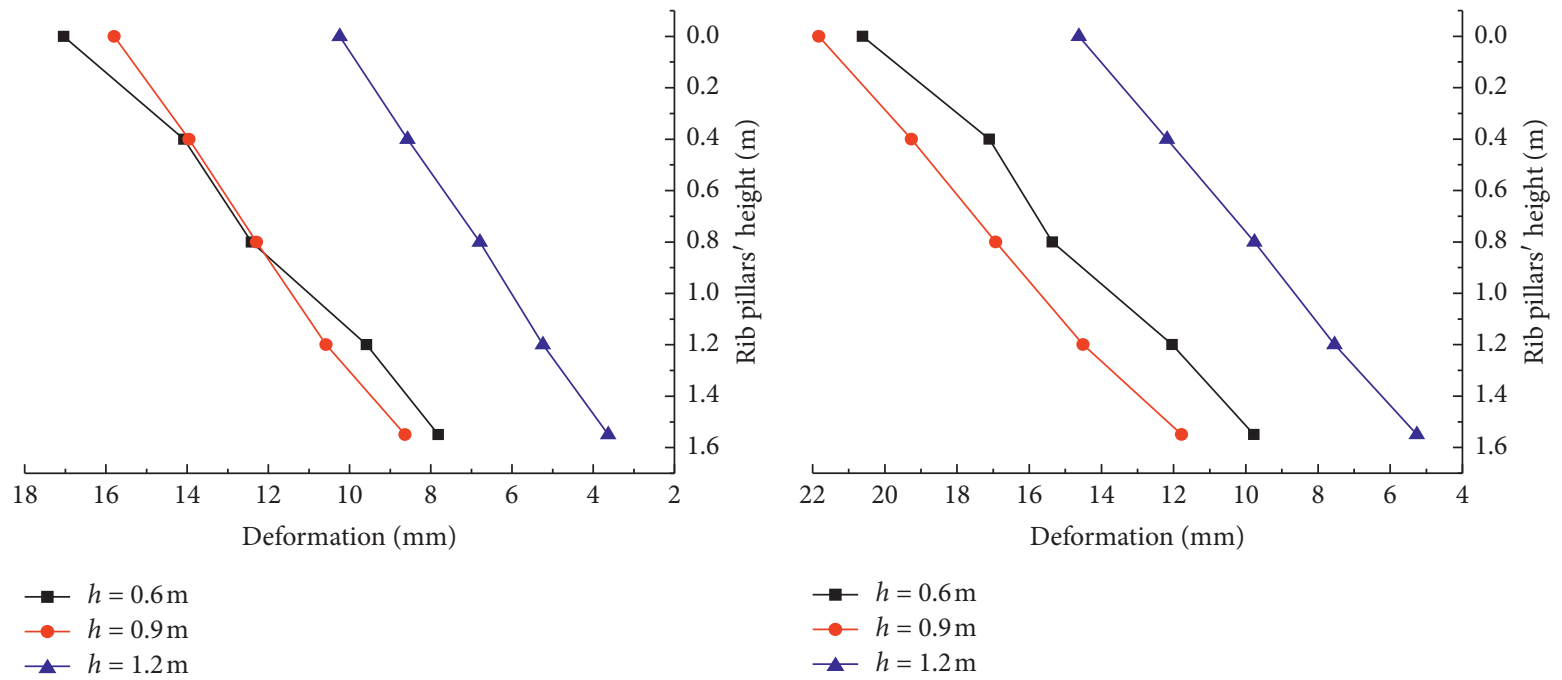

(a)

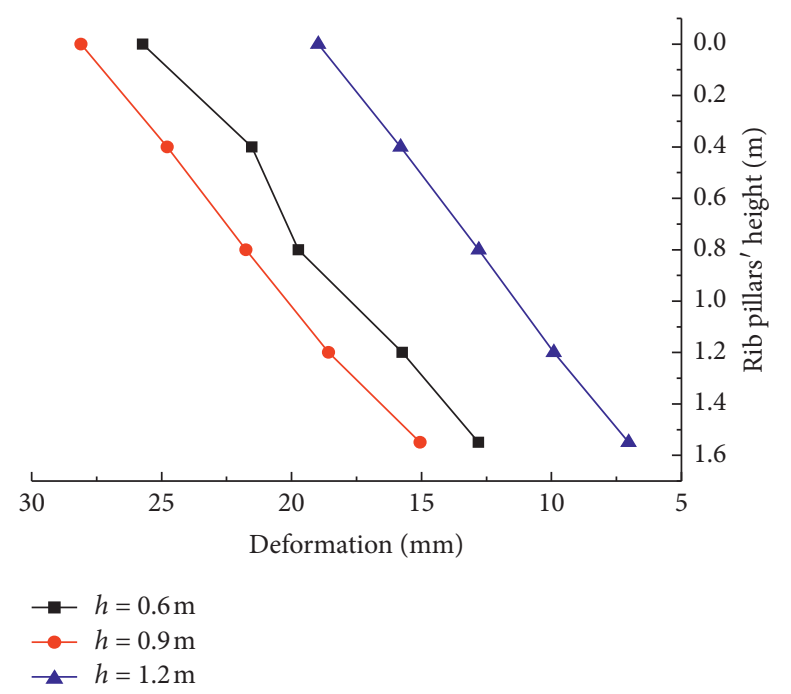

(b)

(c)

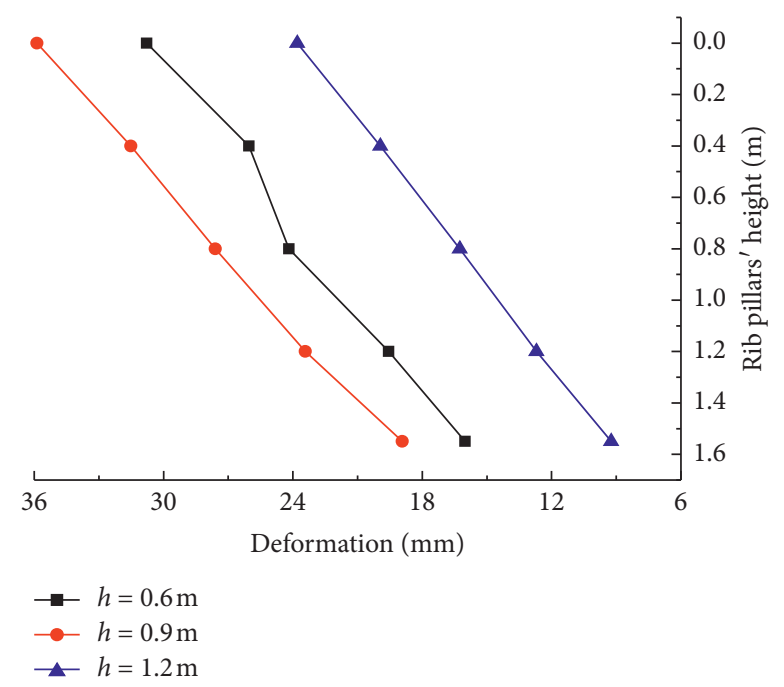

(d)

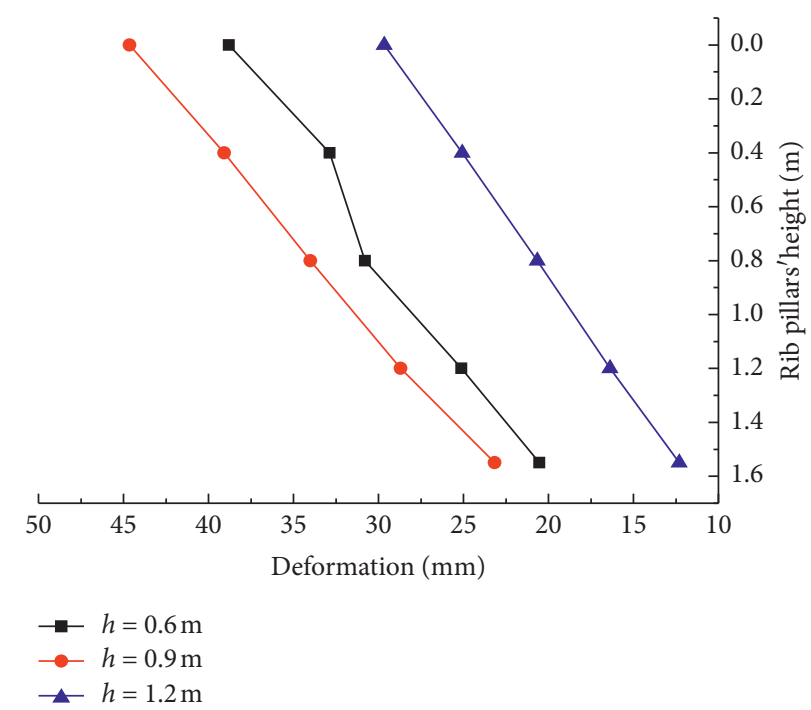

(e)

FIGURE 14: The variation of the deformation of rib pillars with the wall body when $B=0.6 \mathrm{~m}$ at the external load: (a) $B=0.6 \mathrm{~m}(p=10 \mathrm{kPa})$, (b) $B=0.6 \mathrm{~m}(p=20 \mathrm{kPa}),($ c) $B=0.6 \mathrm{~m}(p=30 \mathrm{kPa}),(d) B=0.6 \mathrm{~m}(p=40 \mathrm{kPa})$, and (e) $B=0.6 \mathrm{~m}(p=50 \mathrm{kPa})$. 


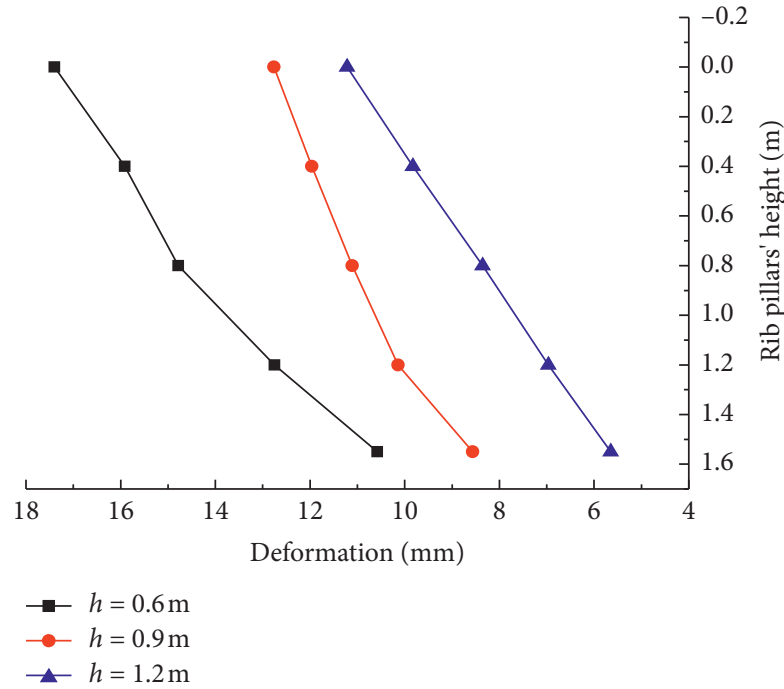

(a)

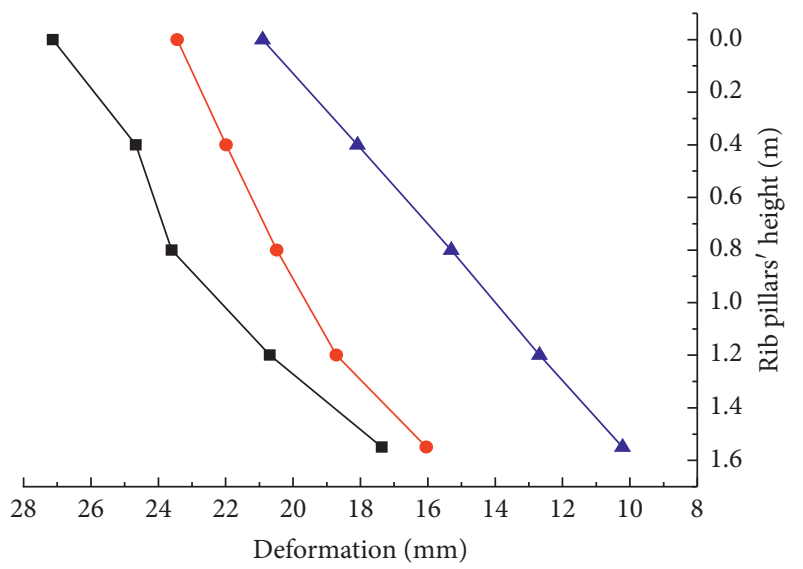

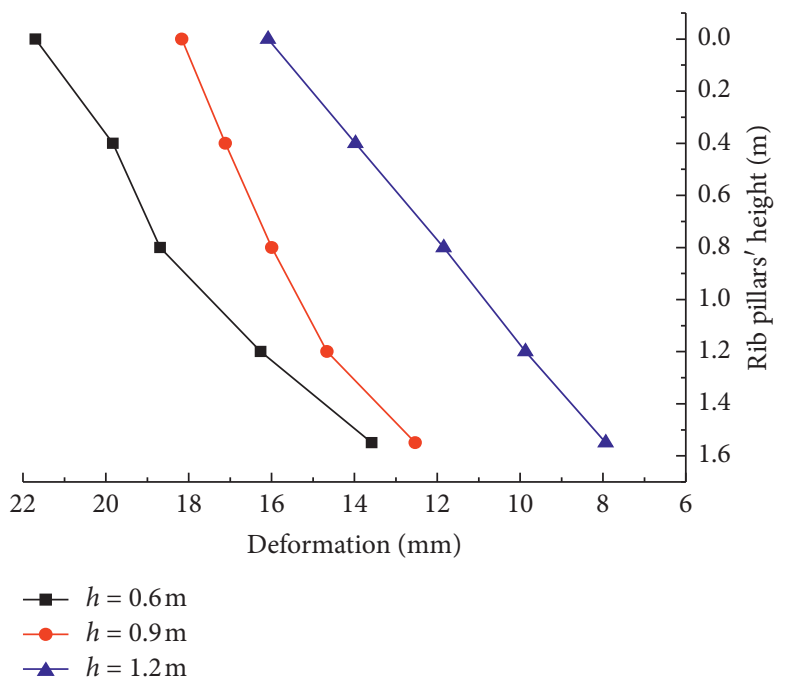

(b)

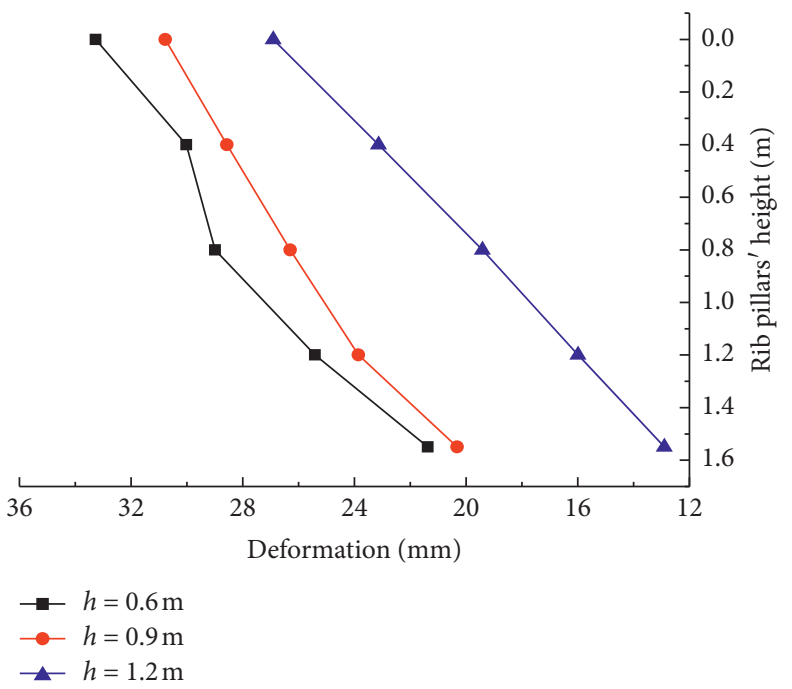

(d)

(c)

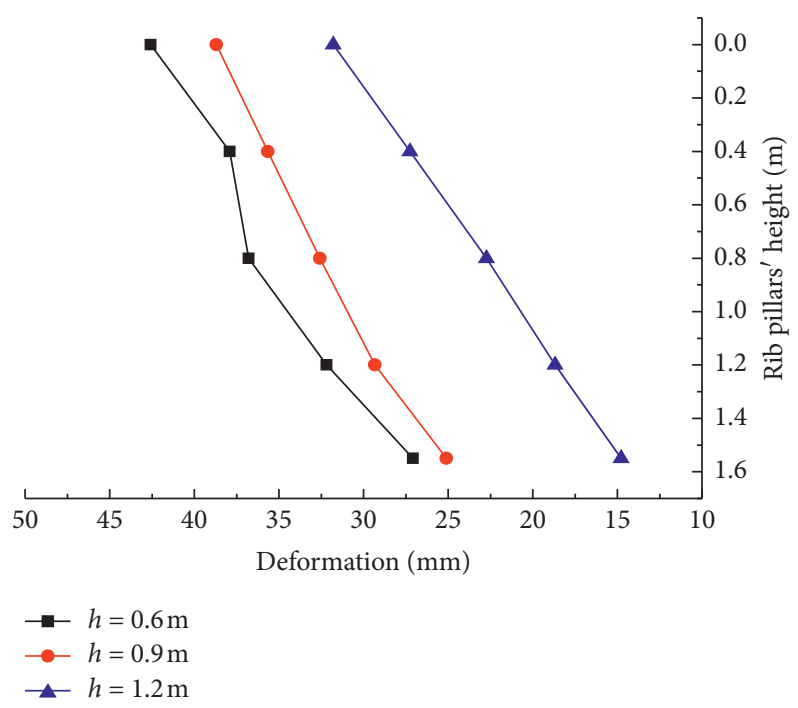

(e)

Figure 15: The variation curve of the deformation of rib pillars with the wall body when $B=1.0 \mathrm{~m}$ at the external load: (a) $B=1.0 \mathrm{~m}$ $(p=10 \mathrm{kPa}),(\mathrm{b}) B=1.0 \mathrm{~m}(p=20 \mathrm{kPa}),(\mathrm{c}) B=1.0 \mathrm{~m}(p=30 \mathrm{kPa}),(\mathrm{d}) B=1.0 \mathrm{~m}(p=40 \mathrm{kPa})$, and (e) $B=1.0 \mathrm{~m}(p=50 \mathrm{kPa})$. 
greater influence on the deformation of rib pillars. However, while $h \leq 0.9 \mathrm{~m}$, the variation with the buried depth under various loads has a smaller influence on the deformation of rib pillars. It indicates that the increase of the buried depth can effectively reduce the deformation of rib pillars at $B=1.0 \mathrm{~m}$, when a certain buried depth is exceeded.

\section{Conclusions}

This study designed the 28-group model tests on the sheet pile wall with a relieving platform, with a similarity ratio of 7 . It was found the influence factors on the deformation of the retaining wall's rib pillars include the installation of the unloading board, the buried depth and width of the unloading board, and the external load. The displacement test results were analyzed, and the following conclusions were drawn:

(1) Without the external load, when the buried depth of the unloading board increases, the influences of the board width on the deformation of rib pillars gradually increase as well. The most suitable width of the unloading board $B$ is $1.2 \mathrm{~m}$ and 0.70 times the wall height if the displacement is the smallest.

(2) Without the external load, when the board width $B=0.5,0.6 \mathrm{~m}$, and $1.2 \mathrm{~m}$, the most suitable buried depth $h$ is $0.9 \mathrm{~m}$ and 0.53 times the wall height. When the unloading board is set at a low position (too large buried depth), the deformation of the retaining wall tends to be the horizontal deformation of the cantilever sheet pile wall. It fails to reduce the deformation of the retaining wall effectively.

(3) Under the combined conditions of $B=0.5 \mathrm{~m}$ and $h=1.2 \mathrm{~m}$ and $B=1.2 \mathrm{~m}$ and $h=0.9 \mathrm{~m}$, the maximum deformation of rib pillars is reduced by $40.3 \%$ and $76.6 \%$, respectively, compared with the maximum deformation of the rib pillars without the unloading board. The setting of the unloading board effectively suppresses the deformation of rib pillars and limits the ratio of the maximum deformation of the rib pillars to their height, within the permitted range of the specification.

(4) With the external load, when the buried depth of the unloading board is relatively shallow $(h=0.6 \mathrm{~m})$ and is relatively deep $(h=1.2 \mathrm{~m})$, the most suitable board width $B$ is $0.6 \mathrm{~m}$ and 0.35 times the wall height. Overlength of the unloading board width fails to reduce the deformation of rib pillars effectively. When the buried depth of the unloading board is moderate $(h=0.9 \mathrm{~m})$, the deformation of rib pillars decreases as the board width increases, and the most suitable board width $B$ is $1.0 \mathrm{~m}$ and 0.60 times the wall height.

(5) With the external load, when the board width is relatively short $(B=0.4 \mathrm{~m}$ and $0.6 \mathrm{~m})$ and the external load is relatively small as well, the most suitable buried depth $h$ is $0.9 \mathrm{~m}$ (moderate) and 0.53 times the wall height. When the external load is large, the most suitable buried depth $h$ is $1.2 \mathrm{~m}$ (relatively large) and 0.70 times the wall height.

(6) With the external load, when $h \geq 0.9 \mathrm{~m}$ (relatively deep), the deformation of rib pillars rapidly decreases as the buried depth increases. However, when $h \leq 0.9 \mathrm{~m}$ (relatively shallow), the influence of the buried depth on the deformation of the rib pillars is relatively smaller. When the width of the unloading board is relatively large $(B=1.0 \mathrm{~m})$, the deformation of the rib pillars under various loads decreases as the buried depth increases.

\section{Data Availability}

The data used to support the findings of this study are included within the article.

\section{Conflicts of Interest}

The authors declare that they have no conflicts of interest.

\section{Acknowledgments}

This work was supported by the National Key R\&D Program of China (no. 2018YFD1100902-1) and the Key Scientific Research Projects of Henan Provincial Colleges and Universities (no. 17A560002) in China.

\section{References}

[1] G. N. Liu, R. H. Hu, and X. H. Pan, "Model tests on mechanical behaviors of sheet pile wall with relieving platform," Chinese Journal of Geotechnical Engineering, vol. 35, no. 1, pp. 103-110, 2013

[2] G. N. Liu, R. H. Hu, and X. H. Pan, "Model tests on earth pressure of upper part wall of sheet pile wall with relieving platform," Rock and Soil Mechanics, vol. 32, no. s2, pp. 94-99, 2011.

[3] S. Sakuma, K. Maehara, T. Funatsu, A. Hamanaka, T. Sasaoka, and H. Shimada, "Analysis of the factors for displacement of earth retaining wall with twin-stepped construction," World Journal of Engineering and Technology, vol. 7, no. 1, pp. 114-121, 2019.

[4] K. Maehara, A. Hamanaka, and T. Sasaoka, "Study on control of wall deflection in earth stepped-twin retaining wall using anchor method by means of numerical simulation," Advances in Civil Engineering, vol. 2020, Article ID 2710954, 8 pages, 2020.

[5] C. Suksiripattanapong, S. Horpibulsuk, A. Chinkulkijniwat et al., "Numerical and sensitivity analysis of bearing reinforcement earth (BRE) Wall," KSCE Journal of Civil Engineering, vol. 21, no. 1, pp. 195-208, 2017.

[6] J.-U. Sim, S.-S. Jeong, and J.-H. Lee, "Numerical analysis of self-supported earth retaining wall with stabilizing piles," Journal of the Korean Geotechnical Society, vol. 31, no. 5, pp. 35-46, 2015.

[7] J. T. Chavda, C. H. Solanki, and A. K. Desai, "Lateral response of contiguous pile wall subjected to staged excavation: physical and numerical investigations," Indian Geotechnical Journal, vol. 49, no. 1, pp. 90-99, 2019.

[8] A. P. Singh and K. Chatterjee, "Ground settlement and deflection response of cantilever sheet pile wall subjected to 
surcharge loading," Indian Geotechnical Journal, vol. 19, pp. 1-10, 2019.

[9] A. P. Singh and K. Chatterjee, "Influence of soil type on static response of cantilever sheet pile walls under surcharge loading: a numerical study," Arabian Journal of Geoscience, vol. 13, p. 138, 2020.

[10] Ö. Bilgin, "Numerical studies of anchored sheet pile wall behavior constructed in cut and fill conditions," Computers and Geotechnics, vol. 37, no. 3, pp. 399-407, 2010.

[11] Q. Bilgin and B. Erten, "Analysis of anchored sheet pile wall deformations,", in Proceedings of the International Foundation Congress and Equipment Expo Ground Modification, Problem Soils, and Geo-Support, pp. 137-144, ASCE, Orlando, FL, USA, 2012.

[12] W.-K. Yoo, B.-I. Kim, I.-J. Moon, and Y.-S. Park, "Comparison of the lateral earth pressure on the retaining wall with the relieving platform by model test and numerical analysis," Journal of the Korea Academia-Industrial Cooperation Society, vol. 13, no. 5, pp. 2382-2389, 2012.

[13] I. Kim, W. K. Yoo, and M. R. Yang, "Model test study on the earth pressure of the retaining wall with the relieving platform," Journal of Korean Society of Civil Engineers, vol. 32, pp. 27-35, 2012.

[14] I.-J. Moon, B.-I. Kim, W.-K. Yoo, and Y.-S. Park, "Model tests for measurement of lateral earth pressure on retaining wall with the relieving platform using Jumoonjin sand," Journal of the Korea Academia-Industrial Cooperation Society, vol. 14, no. 11, pp. 5923-5929, 2013.

[15] M. Faldesai and P. Savoikar, "Comparative analysis and behavior of cantilever retaining wall with and without relief shelves," in Advances in Computer Methods and Geomechanics, vol. 55, pp. 537-551, Springer, Berlin, Germany, 2020.

[16] P. Sekar, S. K. R. Alluri, and S. Suganya, "Effect of relief shelves on cantilever retaining walls," in Lecture Notes in Civil Engineering, vol. 71, pp. 165-178, Springer, Berlin, Germany, 2020.

[17] H. Farouk, "Effectiveness of using shelves with cantilever retaining walls," in Proceedings of the AEI Conference, pp. 627-637, ASCE, Tysons, VA, USA, 2015.

[18] H. F. Shehata, "Retaining walls with relief shelves," in Innovative Infrastructure Solutions, vol. 1, pp. 1-13, , no. 4, Springer, Berlin, Germany, 2016.

[19] I.-J. Moon, B.-I. Kim, and W.-K. Yoo, "Numerical analysis for lateral earth pressure on retaining wall with relieving platform backfilled with Jumoonjin sand," Journal of the Korea Academia-Industrial Cooperation Society, vol. 15, no. 6, pp. 3916-3922, 2014.

[20] I.-J. Moon, B.-I. Kim, J.-T. Han, and A. W. Stuedlein, “Optimal design conditions of retaining wall with relieving platform through real-scale numerical analysis," Journal of the Korean Geotechnical Society, vol. 32, no. 10, pp. 55-65, 2016.

[21] H. F. Shehata, "Use of retaining walls with relief shelves as an economic solution," vol. 257, pp. 82-90, in Proceedings of the Advances in Numerical and Experimental Analysis of Transportation Geomaterials and Geosystems for Sustainable Infrastructure, Fourth Geo-China International Conference, vol. 257, pp. 82-90, ASCE, Shandong, China, 2016.

[22] V. B. Chauhan and S. M Dasaka, "Performance of a rigid retaining wall with relief shelves," Journal of Performance of Constructed Facilities, vol. 32, no. 3, Article ID 04018021, 2018.

[23] H. Tan, Z. Jiao, and J. Chen, "Field testing and numerical analysis on performance of anchored sheet pile quay wall with separate pile-supported platform," Marine Structures, vol. 58, pp. 382-398, 2018.

[24] Y. L. Hu, G. N. Liu, and Y. M. Zhao, "Calculation method of deformation and inner force of a sheet pile wall with relieving platform," in Proceedings of the Fourth International Conference on Transportation Engineering 2013, pp. 172-179, ASCE, Chengdu, China, 2013.

[25] Y. L. Hu, G. N. Liu, and Y. M. Zhao, "Calculation on internal force and deformation of sheet pile wall with relieving platform," Subgrade Engineering, vol. 4, pp. 70-75, 2013.

[26] M. Zhang, W. Wang, and R. H. Hu, "Study on model and tests of sheet pile wall with a relieving platform," Advances in Civil Engineering, vol. 2020, Article ID 8894601, 16 pages, 2020.

[27] R. H. Hu, Study on the mechanical behavior and failure mechanism for sheet pile wall with relieving platform, Ph.D. thesis, China Academy of Railway Sciences, Beijing, China, 2011. 